\title{
Laminin Directs Growth Cone Navigation via Two Temporally and Functionally Distinct Calcium Signals
}

\author{
Thomas B. Kuhn, ${ }^{1}$ Cheri V. Williams, ${ }^{2}$ Ping Dou, ${ }^{2}$ and S. B. Kater ${ }^{3}$ \\ Departments of ${ }^{1}$ Biochemistry and Molecular Biology and ${ }^{2}$ Anatomy and Neurobiology, Colorado State University, Fort \\ Collins, Colorado 80523, and ${ }^{3}$ Department of Anatomy and Neurobiology, University of Utah School of Medicine, Salt \\ Lake City, Utah 84132
}

During development, growth cones navigate to their targets via numerous interactions with molecular guidance cues, yet the mechanisms of how growth cones translate guidance information into navigational decisions are poorly understood. We have examined the role of intracellular $\mathrm{Ca}^{2+}$ in laminin (LN)-mediated growth cone navigation in vitro, using chick dorsal root ganglion neurons. Subsequent to contacting LN-coated beads with filopodia, growth cones displayed a series of stereotypic changes in behavior, including turning toward LN-coated beads and a phase of increased rates of outgrowth after a pause at LN-coated beads. A pharmacological approach indicated that $\mathrm{LN}$-mediated growth cone turning required an influx of extracellular $\mathrm{Ca}^{2+}$, likely in filopodia with $\mathrm{LN}$ contact, and activation of calmodulin (CaM). Surprisingly, fluorescent $\mathrm{Ca}^{2+}$ imaging revealed no $\mathrm{LN}$-induced rise in intracellular $\mathrm{Ca}^{2+}$ in filopodia attached to their parent growth cone. However, isolation of filopodia by laser-assisted transection unmasked a rapid, LNspecific rise in intracellular $\mathrm{Ca}^{2+}(+73 \pm 11 \mathrm{~nm})$. Additionally, a second, sustained rise in intracellular $\mathrm{Ca}^{2+}(+62 \pm 8 \mathrm{~nm})$ occurred in growth cones, with a distinct delay $28 \pm 3$ min after growth cone filopodia contacted LN-coated beads. This delayed, sustained $\mathrm{Ca}^{2+}$ signal paralleled the phase of increased rates of outgrowth, and both events were sensitive to the inhibition of $\mathrm{Ca}^{2+} / \mathrm{CaM}-d e p e n d e n t$ protein kinase II (CaMkinase II) with $2 \mu \mathrm{M} \mathrm{KN-62.} \mathrm{We} \mathrm{propose} \mathrm{that} \mathrm{LN-mediated}$ growth cone guidance can be attributed, in part, to two temporally and functionally distinct $\mathrm{Ca}^{2+}$ signals linked by a signaling cascade composed of CaM and CaM-kinase II.

Key words: $\mathrm{Ca}^{2+}$; laminin; growth cone; filopodia; pathfinding; calmodulin; $\mathrm{Ca}^{2+} /$ calmodulin-dependent protein kinase II
The precise pattern of neuronal connections formed during development depends on the guided advance of growth cones along specific pathways to their appropriate targets. Numerous transient interactions between growth cones and molecular guidance cues in the environment characterize this period of growth cone pathfinding (Hynes and Lander, 1992; Goodman and Shatz, 1993). The underlying mechanisms of how growth cones receive, interpret, and translate guidance information into navigational decisions are poorly understood. Recent evidence indicates that receptor-activated signal transduction mechanisms regulate advance, navigation, and target recognition of growth cones (Doherty and Walsh, 1994; Kuhn et al., 1995; Tanaka and Sabry, 1995).

The second messenger $\mathrm{Ca}^{2+}$ is a potent and versatile regulator of growth cone behavior and morphology (Kater and Mills, 1991) (for review, see Clapham, 1995; Ghosh and Greenberg, 1995). Growth cones respond to a local source of acetylcholine with a rise in the free intracellular $\mathrm{Ca}^{2+}$ concentration $\left(\left[\mathrm{Ca}^{2+}\right]_{i}\right)$ and navigate toward increasing neurotransmitter concentrations (Zheng et al., 1994). Davenport et al. $(1993,1996)$ have demonstrated that surgically isolated filopodia do react to neurotrans-

\footnotetext{
Received June 18, 1997; revised Sept. 25, 1997; accepted Oct. 17, 1997.

This work was supported by a fellowship from the Swiss National Foundation to T.B.K. and National Institutes of Health Grant NS24683 to S.B.K. We thank Drs. Jim Bamburg and Mark Wright for critical comments and helpful suggestions on this manuscript. Also, we thank Dennis Giddings and Christine Porter for technical assistance.

Correspondence should be addressed to Dr. Thomas B. Kuhn, Department of Biochemistry and Molecular Biology, Colorado State University, Fort Collins, CO 80523.

Copyright (C) 1997 Society for Neuroscience $\quad 0270-6474 / 97 / 180184-11 \$ 05.00 / 0$
}

mitter application with a rise of $\left[\mathrm{Ca}^{2+}\right]_{\mathrm{i}}$. The exchange of $\mathrm{Ca}^{2+}$ ions through gap junctions occurs during interactions of pioneer growth cones with guidepost cells (Bentley et al., 1991). L1, NCAM, and $N$-cadherin promote neurite outgrowth by stimulating a $\mathrm{Ca}^{2+}$ influx through voltage-gated $\mathrm{L}$ - and $\mathrm{N}$-type calcium channels (Doherty et al., 1991; Williams et al., 1992). Also, the extracellular matrix protein $\mathrm{LN}$ induces small but significant rises of $\left[\mathrm{Ca}^{2+}\right]_{\mathrm{i}}$ in ciliary ganglion neurons when applied in soluble form to the culture medium (Bixby et al., 1994). Several types of $\mathrm{Ca}^{2+}$ channels, homogeneously distributed or clustered, have been identified on neuronal growth cones (Bolsover and Spector, 1986; Silver et al., 1990) (for review, see Gottmann and Lux, 1995). Furthermore, modification of $\mathrm{Ca}^{2+}$-activated proteins disrupted growth cone behavior, providing additional evidence for a role of $\mathrm{Ca}^{2+}$ in regulating growth cone behavior. Expression of inactive calmodulin (CaM) in Drosophila resulted in severe pathfinding errors of pioneer growth cones (VanBerkum and Goodman, 1995). Also, overexpression of CaM-kinase II caused a prolonged, increased neurite outgrowth (Goshima et al., 1993), whereas CaM-kinase II inhibition decreased neurite outgrowth (Solem et al., 1995; Williams et al., 1995).

In the present study we investigated the role of intracellular $\mathrm{Ca}^{2+}$, CaM, and CaM-kinase II in LN-mediated growth cone guidance in vitro, using a pharmacological approach combined with fluorescent $\mathrm{Ca}^{2+}$ imaging. LN-coated beads, polystyrene beads covalently coupled with $\mathrm{LN}$, represented a spatially restricted guidance stimulus. Growth cones contacting these LNcoated beads displayed a series of stereotypic growth cone responses reflected by changes in behavior and morphology (Kuhn et al., 1995). Two temporally and functionally distinct rises in 
$\left[\mathrm{Ca}^{2+}\right]_{\mathrm{i}}$, linked by a sequential activation of $\mathrm{CaM}$ and CaMkinase II, constituted a mechanism underlying growth cone guidance provided by a singular LN stimulus. Additionally, individual growth cone responses could be attributed to individual second messenger activities.

\section{MATERIALS AND METHODS}

Materials. LN, fibronectin (FN), and 2.5s NGF were obtained from Collaborative Biomedical Research (Bedford, MA). MEM and HBSS were from Life Technologies (Gaithersburg, MD). FBS was purchased from HyClone (Logan, UT). Carboxylated polystyrene beads, together with coupling reagents, were obtained from Polyscience (Warrington, PA). Fura-2AM and AM-BAPTA were from Molecular Probes (Eugene, OR). Bisindolylmaleimide, $\mathrm{KN}-62$, and fluphenazine- $N$-2-chloroethane (FPC) were obtained from Calbiochem (San Diego, CA). All other chemicals were from Sigma (St. Louis, MO).

Cell culture. Dorsal root ganglia (DRG) from 10-d-old white Leghorn chick embryos were dissociated mechanically and enzymatically $(0.1 \%$ trypsin/HBSS for $10 \mathrm{~min}$ at $\left.37^{\circ} \mathrm{C}\right)$ and preplated $\left(7.5 \% \mathrm{CO}_{2}\right.$ for $2 \mathrm{hr}$ at $37^{\circ} \mathrm{C}$ ) in MEM, $26.2 \mathrm{~mm} \mathrm{NaHCO}_{3}, 2 \mathrm{~mm}$ glutamine, and $10 \% \mathrm{FBS}$. Nonadherent cells were resuspended in MEM, $26.2 \mathrm{~mm} \mathrm{NaHCO}_{3}, 2 \mathrm{~mm}$ glutamine, $10 \% \mathrm{FBS}, 20 \mathrm{ng} / \mathrm{ml} 2.5 \mathrm{~s} \mathrm{NGF}$, and $1 \% \mathrm{~N} 3$ supplement, $\mathrm{pH} 7.3$ $(325 \pm 5 \mathrm{mOsm})$ and plated on $2 \mu \mathrm{g} / \mathrm{cm}^{2} \mathrm{FN}(25,000 \mathrm{cells} / \mathrm{ml})$. FN was adsorbed $\left(2 \mathrm{hr}\right.$ at $\left.37^{\circ} \mathrm{C}\right)$ to dry poly-L-lysine-coated $\left(80 \mu \mathrm{g} / \mathrm{cm}^{2}\right)$ glass coverslips inserted into $35 \mathrm{~mm}$ Falcon culture dishes, washed three times with HBSS, and used immediately.

Inhibitors. The half-maximal inhibitory concentration $\left(\mathrm{IC}_{50}\right)$ of every inhibitor was determined from the dose dependence of neurite outgrowth of DRG neurons on $\mathrm{FN}$ by adding inhibitors (concentrations used: $0.5 \times \mathrm{IC}_{50}, 1 \times \mathrm{IC}_{50}$, and $2 \times \mathrm{IC}_{50}$ ) to dissociated DRG neurons after the onset of neurite outgrowth. Cultures were preincubated for 20 min with the particular inhibitor, and the growth rates were determined. None of the inhibitors $\left(\mathrm{IC}_{50}\right.$ or lower concentrations) affected growth cone advance on $\mathrm{FN}$ over a time period of $60 \mathrm{~min}$. In the standard assay, inhibitors were added 15 min before $\mathrm{LN}$-coated beads were positioned (concentration used equals $\mathrm{IC}_{50}$ ).

Standard LN-coated bead assay. LN was coupled covalently to polystyrene beads, exposing carboxyl groups on their surface as previously described (Kuhn et al., 1995). Briefly, polystyrene beads $(4.5 \mu \mathrm{m}$ in diameter) were activated with $1 \%$ carbodiimide, $\mathrm{pH} 7$, for $4 \mathrm{hr}$ at $\mathrm{RT}$ and then washed three times with borate buffer. LN $(50 \mu \mathrm{g})$ was coupled to $10^{8}$ beads/ml (volume, $1 \mathrm{ml}$ ), and the remaining active groups were blocked with ethanolamine and BSA. Estimated coupling yields were routinely $>65 \%$ with SDS-PAGE silver staining.

LN-coated beads were presented to advancing DRG growth cones as previously described (Kuhn et al., 1995). Culture medium was exchanged to a serum-free defined medium (MEM, 10 mM HEPES, $1 \%$ N3 supplement, $20 \mathrm{ng} / \mathrm{ml} 2.5 \mathrm{~s} \mathrm{NGF}, 5 \mathrm{mg} / \mathrm{ml}$ ovalbumin, and $2 \mathrm{~mm}$ glutamine, $\mathrm{pH}$ $7.3 ; 325 \pm 5 \mathrm{mOsm}), \mathrm{LN}$-coated beads were added, and mineral oil was overlaid to prevent evaporation (assay temperature, $37^{\circ} \mathrm{C}$ ). LN-coated beads were manipulated in space with a LaserTweezer optical system LT-1000, using a $100 \mathrm{~mW}$ diode laser with an emission wavelength of 830 nm (Cell Robotics, Albuquerque, NM). A Nikon inverted microscope was equipped with a CCD camera (Hitachi Denshi, model KP-MF1V) and a computer-controlled microscopic stage (MLC-3, Märzhäuser Wetzlar GMBH). Images were acquired at $100 \times$ (Zeiss oil objective) with a MAC CI II and analyzed with the program Image 1.49 (National Institutes of Health, Bethesda, MD). In the pharmacological approach, inhibitors were added 15 min before the addition of LN-coated beads.

Measurement of intracellular calcium. DRG neurons were loaded with 2 $\mu \mathrm{M}$ fura-2AM (Molecular Probes) in MEM, 10\% FBS, $20 \mathrm{ng} / \mathrm{ml} \mathrm{2.5 \textrm {s }}$ $\mathrm{NGF}, 1 \% \mathrm{~N} 3$ supplement, $26.2 \mathrm{~mm} \mathrm{NaHCO}$, and $2 \mathrm{~mm}$ glutamine for 30 min at $37^{\circ} \mathrm{C}$. After three washes, DRG neurons were allowed to deesterify for $30 \mathrm{~min}$ in the same medium (identical procedure for AMBAPTA). Then the cultures were transferred to a serum-free defined medium containing MEM without phenol red to reduce background fluorescence. $\mathrm{Ca}^{2+}$ imaging was performed with a $40 \times$ oil objective (Nikon, Fluor 1.30) and a cooled CCD camera (Photometrics, Tucson, AZ) linked to an image-processing system. Images were acquired at two excitation wavelengths (350 and $380 \mathrm{~nm}$ ), and fluorescent emission was filtered with a $495 \mathrm{~nm}$ long-pass filter. The ratio of each pair of the 350 and $380 \mathrm{~nm}$ images was determined on a pixel-by-pixel basis, and $\left[\mathrm{Ca}^{2+}\right]$ was estimated according to Grynkiewicz et al. (1985). The systemspecific values were $R_{\text {min }}=0.27, R_{\max }=6.90$, and $F_{\mathrm{o}} / F_{\mathrm{s}} \cdot K_{\mathrm{D}}=739$. This
$\mathrm{Ca}^{2+}$ imaging system was not equipped with laser tweezers. As our criterion, a change in $\left[\mathrm{Ca}^{2+}\right]_{i}$ was considered positive when it was $>2 \mathrm{SD}$ above average resting $\left[\mathrm{Ca}^{2+}\right]_{\mathrm{i}}$. The significance of our results remained unchanged when 1 SD above average resting $\left[\mathrm{Ca}^{2+}\right]_{i}$ was applied as a less-stringent criterion.

Surgical isolation of individual filopodia. Cultures of DRG neurons were loaded with $5 \mu \mathrm{M}$ fura-2AM for $35 \mathrm{~min}$ at $37^{\circ} \mathrm{C}$ to ensure the strong loading of filopodia. While deesterifying, individual filopodia were transected from parent growth cones via a Laser scissors system $(360 \mathrm{~nm}$ cutting wavelength; Cell Robotics). To measure $\left[\mathrm{Ca}^{2+}\right]_{i}$, we transferred cultures to the $\mathrm{Ca}^{2+}$ imaging system and relocated growth cones with surgically isolated filopodia.

\section{RESULTS}

\section{LN-mediated growth cone turning requires an influx of extracellular $\mathrm{Ca}^{2+}$}

In the standard assay, chick DRG growth cones advanced on a uniform FN substrate and encountered LN-coated beads manipulated in space by optical trapping with laser tweezers. In control conditions, growth cones displayed a series of stereotypic responses characterized by changes in their behavior and morphology when they encountered LN-coated beads (Fig. 1A). Typically, growth cones sampled LN-coated beads by repetitive touching with individual filopodia before the formation of longlasting adhesive contacts with single filopodia. As a result, growth cones changed their original course of advance (turning) and approached LN-coated beads. After an extended pause at beads (14 $\pm 3 \mathrm{~min} ; n=12)$, growth cones advanced beyond LN-coated beads with twofold increased rates of outgrowth for considerable distances until the restoration of growth rates as before contact (Kuhn et al., 1995). Positive growth cone turning was defined as a deviation from the original course of advance $>15^{\circ}$. According to this criterion $79 \pm 1 \%(n=21)$ of growth cones investigated responded positively (Fig. 2).

In contrast, growth cones ignored $\mathrm{LN}$-coated beads when preloaded with AM-BAPTA $\left(2 \mu \mathrm{M} ; K_{\mathrm{D}}=340 \mathrm{nM}\right)$ to chelate elevations in $\left[\mathrm{Ca}^{2+}\right]_{i}$. Growth cones maintained their original course of advance despite sampling of LN-coated beads with individual filopodia and long-lasting filopodial adhesion (Fig. $1 B)$. Under these conditions only $19 \pm 1 \%(n=21 ; p<0.01)$ of growth cones that were investigated responded positively (Fig. 2). Also, nominal zero extracellular $\mathrm{Ca}^{2+}\left(2 \mathrm{~mm}\right.$ EGTA in a $\mathrm{Ca}^{2+}$. free medium) reduced the number of positively responding growth cones $(22 \pm 5 \%, n=13 ; p<0.001)$. Similarly, general $\mathrm{Ca}^{2+}$ channel blockers such as $2 \mathrm{mM} \mathrm{Ni}^{2+}(11 \pm 4 \%$ growth cones responding positively, $n=17 ; p<0.001$ ) or $2 \mathrm{mM} \mathrm{Co}^{2+}$ $(6 \pm 3 \%$ growth cones responding positively, $n=15 ; p<0.05)$ abolished growth cone turning. These inhibitors disrupted the series of stereotypic growth cone responses as detailed for AMBAPTA conditions. Importantly, none of the inhibitors altered growth cone migration on $\mathrm{FN}$ at concentrations used in the standard assay (observation time, $60 \mathrm{~min}$ ) (Table 1). This finding implied that inhibitors specifically blocked LN-signaled growth cone turning and not indirectly by lowering resting levels of $\left[\mathrm{Ca}^{2+}\right]_{\mathrm{i}}$ in growth cones. However, $4 \mathrm{mM} \mathrm{Ni}^{2+}$ or $\mathrm{Co}^{2+}$ caused growth cone collapse and neurite retraction. Growth cone detachment and significant changes in growth cone morphology were observed in $5 \mathrm{~mm}$ EGTA and with $4 \mu \mathrm{M}$ BAPTA, respectively. These effects were observed later than $30 \mathrm{~min}$ after the addition of inhibitors at high concentration. In conclusion, this pharmacological study suggests that an LN-stimulated influx of extracellular $\mathrm{Ca}^{2+}$ is required for subsequent growth cone turning. It is conceivable that this $\mathrm{Ca}^{2+}$ influx occurs in filopodia at the contact site with LN-coated beads. 


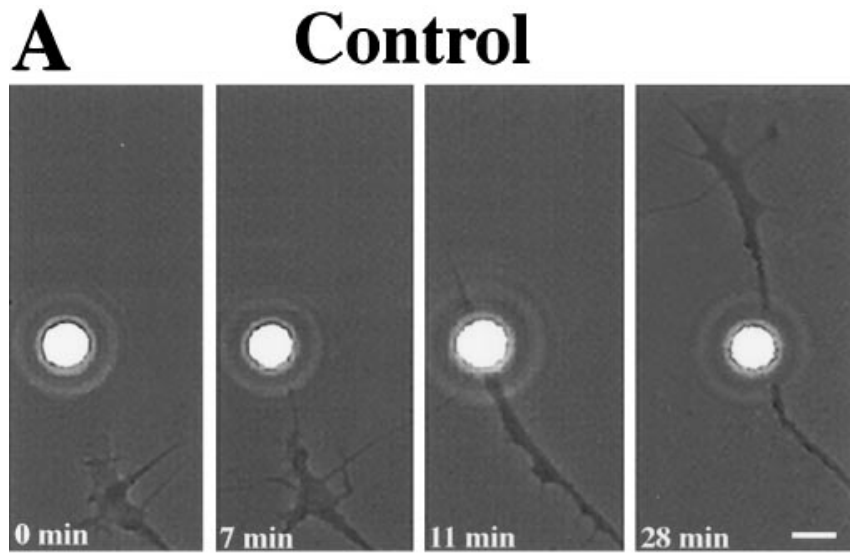

\section{B AM-BAPTA}
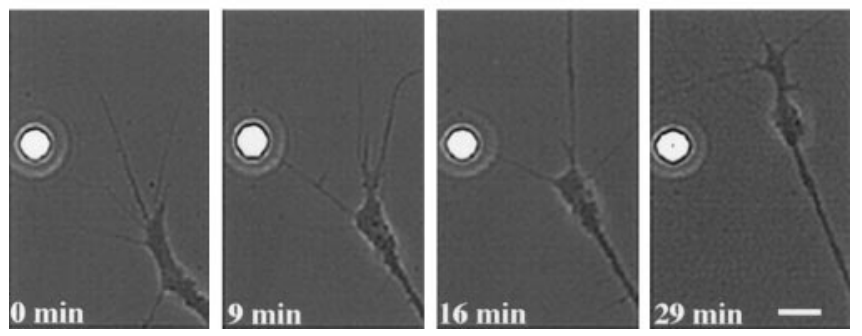

Figure 1. LN-mediated growth cone guidance is characterized by a series of stereotypic changes in growth cone behavior and requires a rise of $\left[\mathrm{Ca}^{2+}\right]_{\mathrm{i}} . A, \mathrm{~A}$ chick DRG growth cone, advancing on $\mathrm{FN}$, approaches an LN-coated bead $(t=0 \mathrm{~min})$. The growth cones touches the LN-coated bead with a single filopodium and establishes a long-lasting filopodial contact $(t=7 \mathrm{~min})$. The growth cone changes its original course of advance (turning), approaches the LN-coated bead, and pauses in close proximity $(t=11 \mathrm{~min})$. Then the growth cone continues to advance beyond the $\mathrm{LN}$-coated bead $(t=28 \mathrm{~min})$ with increased rates of outgrowth for considerable distances. $B$, Chelating an elevation of $\left[\mathrm{Ca}^{2+}\right]_{\mathrm{i}}$ with AM-BAPTA blocks LN-mediated growth cone turning. A growth cone, loaded previously with AM-BAPTA, approaches an LNcoated bead $(t=0 \mathrm{~min})$. Although long-lasting filopodial contact is established ( $t=9 \mathrm{~min}$ ), the growth cone is unable to translate guidance instructions provided by the $\mathrm{LN}$-coated bead into a navigational decision $(t=16 \mathrm{~min})$ and simply passes by $(t=29 \mathrm{~min})$. Scale bar, $4.5 \mu \mathrm{m}$. Bead diameter, $4.5 \mu \mathrm{m}$.

\section{CaM activity is essential for growth cone turning}

$\mathrm{A} \mathrm{Ca}^{2+}$ influx into growth cones induced by $\mathrm{LN}$-coated bead contact could activate numerous target proteins such as $\mathrm{CaM}$, a major intracellular $\mathrm{Ca}^{2+}$ receptor. $\mathrm{CaM}$ is very abundant in filopodia and growth cone bodies (Letourneau et al., 1994), where it is targeted to the inner plasma membrane via an association with GAP-43 (Alexander et al., 1987). Phosphorylation of GAP-43 by $\mathrm{Ca}^{2+}$-dependent protein kinase $\mathrm{C}$ (PKC) can cause dissociation of the CaM/GAP-43 complex, resulting in the formation of $\mathrm{Ca}^{2+} / \mathrm{CaM}$. In fact, PKC activity is critical for growth cone turning signaled by LN-coated beads (Kuhn et al., 1995). $\mathrm{Ca}^{2+} / \mathrm{CaM}$ binds to, thus activating, a large number of target proteins, including the $\alpha$ and $\beta$ isoforms of CaM-kinase II, both highly enriched in neurons (for review, see Schulman, 1988; Brocke et al., 1995). Thus, we tested whether CaM and CaMkinase II activity were necessary for LN-mediated growth cone navigation.

The addition of $10 \mu \mathrm{M}$ FPC, an irreversible $\mathrm{Ca}^{2+} / \mathrm{CaM}$ inhib-

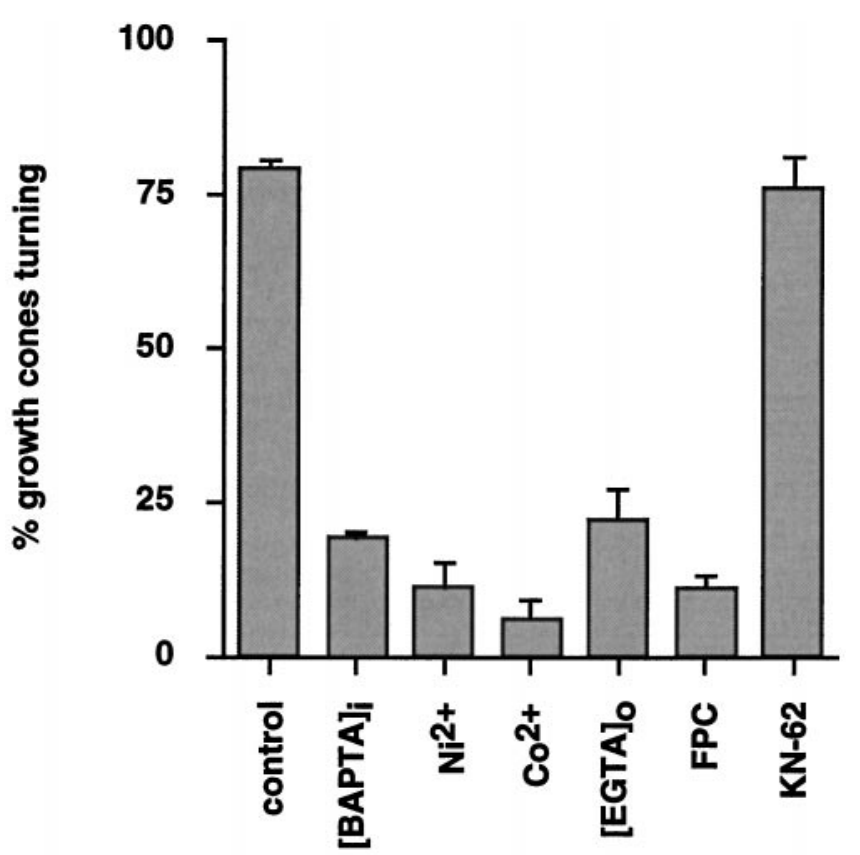

Figure 2. Growth cone turning toward LN-coated beads requires an influx of extracellular $\mathrm{Ca}^{2+}$ and $\mathrm{CaM}$ activity. A deviation of the original course of advance $>15^{\circ}$ defined a positive growth cone turning response. Under control conditions, $>75 \%$ of growth cones that were investigated respond positively. Blocking $\mathrm{Ca}^{2+}$ channels $\left(2 \mathrm{~mm}\right.$ each, $\mathrm{Ni}^{2+}$ and $\left.\mathrm{CO}^{2+}\right)$ or chelating extracellular $\mathrm{Ca}^{2+}\left([E G T A]_{\mathrm{o}}\right)$ or intracellular $\mathrm{Ca}^{2+}([A M-$ $\left.B A P T A]_{\mathrm{i}}\right)$ significantly reduces the number of growth cone turnings. Inhibition of $\mathrm{CaM}$ with $10 \mu \mathrm{M}$ fluphenazine-2- $N$-chloroethane $(F P C)$ blocks growth cone turning, whereas inhibition of CaM-kinase II $(2 \mu \mathrm{M}$ $K N-62)$ is ineffective. None of the inhibitors tested altered growth cone advance on the FN substrate for the time period of observation. The significance of the effects of each inhibitor was compared with a parallel control $(t$ test). Control value shown is an average of all controls. Error bars indicate SEM.

Table 1. Dose-dependent effects of inhibitors on growth cone migration on fibronectin

\begin{tabular}{ll} 
Conditions & Growth cone velocity $(\mu \mathrm{m} / \mathrm{hr})$ \\
\hline Control & $32 \pm 4^{b}$ \\
$2 \mathrm{~mm}$ EGTA & $33 \pm 3$ \\
$5 \mathrm{mM} \mathrm{EGTA}^{2+}$ & $22 \pm 3^{a}$ \\
$2 \mathrm{mM} \mathrm{Ni}^{2+}$ & $29 \pm 7$ \\
$4 \mathrm{mM} \mathrm{Ni}^{2+}$ & $23 \pm 6^{a}$ \\
$2 \mathrm{mM} \mathrm{Co}^{2+}$ & $33 \pm 9$ \\
$4 \mathrm{mM} \mathrm{Co}^{2+}$ & $15 \pm 4^{a}$ \\
$2 \mu \mathrm{M}$ BAPTA & $33 \pm 3$ \\
$4 \mu \mathrm{M}$ BAPTA & $\mathrm{nd}$ \\
$10 \mu \mathrm{M}$ FPC & $29 \pm 4$ \\
$20 \mu \mathrm{M} \mathrm{FPC}$ & $7 \pm 3^{a}$ \\
$2 \mu \mathrm{M} \mathrm{KN}-62$ & $31 \pm 3$ \\
$4 \mu \mathrm{M} \mathrm{KN}-62$ & $13 \pm 2^{a}$
\end{tabular}

${ }^{a}$ Parallel control experiments were performed for each inhibitor ( $t$ test).

${ }^{b}$ Average growth cone velocity of all control experiments. nd, Not determined. $4 \mu \mathrm{M}$ BAPTA significantly changed growth cone morphology.

itor (Hait et al., 1987; Alvarez et al., 1991), negated growth cone turning (11 $\pm 2 \%$ positively responding growth cones, $n=20 ; p<$ 0.005 ) according to the criterion set above (Fig. 2). Growth cone behavior was identical to that described for AM-BAPTA. In contrast, $2 \mu \mathrm{M} \mathrm{KN}-62$, a specific CaM-kinase II inhibitor 
(Tokumitsu et al., 1990), had no effect on growth cone turning (76 $\pm 5 \%$ growth cones responding positively, $n=18$ ) as compared with control $(79 \pm 1 \%$ growth cones responding, $n=21)$. Longer preincubation of DRG neurons with $2 \mu \mathrm{M} \mathrm{KN}-62$, sufficient to block CaM-kinase II activity in other cell types (Tokumitsu et al., 1990), was also unsuccessful in blocking growth cone turning. Neither $10 \mu \mathrm{M}$ FPC nor $2 \mu \mathrm{M}$ KN-62 altered growth cone migration on $\mathrm{FN}$, indicating the specificity of their effects in the standard assay (Table 1). These data imply that $\mathrm{CaM}$ is a primary target of the LN-stimulated $\mathrm{Ca}^{2+}$ influx and that $\mathrm{Ca}^{2+} /$ $\mathrm{CaM}$ is critical to mediate growth cone turning. Subsequent activation of CaM-kinase II is not required for LN-mediated growth cone turning in this assay system.

\section{CaM-kinase II: a regulator of increased rates of outgrowth signaled by LN}

Several studies have linked CaM-kinase II activity to increased neurite outgrowth (Goshima et al., 1993; Solem et al., 1995; Williams et al., 1995). Because CaM-kinase II was not required for LN-signaled growth cone turning, we tested whether CaMkinase II activity was necessary for growth cone behaviors occurring late in the series of stereotypic responses, such as increased rates of outgrowth.

As illustrated in Figure $3 a$, growth rates on FN significantly increased after transient LN-coated bead contact $(117 \pm 14$ $\mu \mathrm{m} / \mathrm{hr}, n=8 ; p<0.001)$ as compared with growth rates before contact (45 $\pm 13 \mu \mathrm{m} / \mathrm{hr}, n=8)$, consistent with previous findings (Kuhn et al., 1995). Increased rates of outgrowth lasted for considerable distances beyond $\mathrm{LN}$-coated beads until restoration to FN-like characteristics occurred. In the standard assay, $2 \mu \mathrm{M}$ $\mathrm{KN}-62$ abolished the period of increased rates of outgrowth (44 $\pm 8 \mu \mathrm{m} / \mathrm{hr}, n=17$ ) as compared with growth rates measured before LN-coated bead contact $(43 \pm 7 \mu \mathrm{m} / \mathrm{hr}, n=8)$. The addition of $20 \mu \mathrm{l}$ of soluble LN (20 $\mu \mathrm{g} / \mathrm{ml})$ to chick DRG growth cones advancing on $\mathrm{FN}$ increased the rates of outgrowth (Fig. $3 b, c)$, in agreement with Rivas et al. (1992). Growth rates of $63 \pm$ $10 \mu \mathrm{m} / \mathrm{hr}(n=11 ; p<0.01)$ were measured $30 \mathrm{~min}$ after application of $\mathrm{LN}$ as opposed to $35 \pm 3 \mu \mathrm{m} / \mathrm{hr}(n=11)$ before the addition of $\mathrm{LN}$. This resulted in a net increase of rates of outgrowth by $+80 \pm 16 \%(n=11)$ as determined 30 min after $\mathrm{LN}$ application. The presence of $2 \mu \mathrm{M}$ KN-62 prevented this growth-promoting effect of soluble LN $(32 \pm 5 \mu \mathrm{m} / \mathrm{hr}, n=8$, $+3 \pm 16 \%$ increase) as compared with growth rates before the addition of $\mathrm{LN}(31 \pm 3 \mu \mathrm{m} / \mathrm{hr}, n=8)$. Furthermore, growth cone advance on FN was not altered in the presence of $2 \mu \mathrm{M} \mathrm{KN}-62$ ( $29 \pm 6 \mu \mathrm{m} / \mathrm{hr}, n=8$ ) as opposed to growth rates on $\mathrm{FN}$ in the absence of KN-62 (37 $\pm 5 \mu \mathrm{m} / \mathrm{hr}, n=8 ; p>0.05)$. Activation of CaM-kinase II critically depends on a preceding elevation of $\left[\mathrm{Ca}^{2+}\right]_{\mathrm{i}}$. Therefore, preventing a rise of $\left[\mathrm{Ca}^{2+}\right]_{\mathrm{i}}$ should block increased rates of outgrowth. Chelating rises of $\left[\mathrm{Ca}^{2+}\right]_{i}$ by preloading neurons with $2 \mu \mathrm{M}$ AM-BAPTA indeed negated the phase of increased rates of outgrowth caused by the addition of soluble LN (Fig. 3c). With intracellular BAPTA, rates of outgrowth before the addition of $\mathrm{LN}(36 \pm 3 \mu \mathrm{m} / \mathrm{hr}, n=14)$ were identical to rates measured $30 \mathrm{~min}$ after the addition of $\mathrm{LN}$ (31 \pm $3 \mu \mathrm{m} / \mathrm{hr}, n=14)$. It is noteworthy that rates of outgrowth in the absence of intracellular BAPTA were indistinguishable from those determined in the presence of intracellular BAPTA (Table 1; Fig. $3 c)$. This suggested that resting $\left[\mathrm{Ca}^{2+}\right]_{\mathrm{i}}$ in advancing growth cones was not lowered significantly by the $\mathrm{Ca}^{2+}$ chelator BAPTA. These results demonstrated that CaM-kinase II activ- ity, preceded by a rise of $\left[\mathrm{Ca}^{2+}\right]_{\mathrm{i}}$, is necessary for $\mathrm{LN}$-mediated increased rates of outgrowth.

Taken together, our pharmacological data indicate that both an influx of extracellular $\mathrm{Ca}^{2+}$ and the formation of $\mathrm{Ca}^{2+} / \mathrm{CaM}$ are required for $\mathrm{LN}$-mediated growth cone turning. In contrast, CaM-kinase II activity is necessary only for increased rates of outgrowth stimulated by LN-coated bead contact.

\section{$A$ rapid rise in $\left[\mathrm{Ca}^{2+}\right]_{\mathrm{i}}$ in filopodia with $\mathrm{LN}$ contact}

We used fluorescent $\mathrm{Ca}^{2+}$ imaging with the membranepermeable calcium indicator fura-2AM $(2 \mu \mathrm{M})$ to quantify the magnitude of the $\mathrm{Ca}^{2+}$ influx and to determine whether changes in $\left[\mathrm{Ca}^{2+}\right]_{\mathrm{i}}$ occurred in filopodia adhering to $\mathrm{LN}$-coated beads and/or in the parent growth cones. LN-coated beads were dispersed into cultures of fura-loaded DRG neurons, and the cultures were screened for possible growth cone encounters because our $\mathrm{Ca}^{2+}$ imaging system was not equipped with laser tweezers. Fura-loaded growth cones responded to LN-coated bead encounters with a similar series of stereotypic changes in behavior. Surprisingly, ratiometric $\mathrm{Ca}^{2+}$ imaging during growth cone encounters revealed no rise of $\left[\mathrm{Ca}^{2+}\right]_{i}$ either in filopodia adhering to $\mathrm{LN}$-coated beads or in parent growth cones, according to the criteria set, despite our pharmacological approach that suggested an LN-stimulated influx of extracellular $\mathrm{Ca}^{2+}$ (see Materials and Methods). We postulated that the $\mathrm{Ca}^{2+}$ signal could be masked because of the properties of the intact physical connection beteen filopodia and parent growth cones (Figs. 4-6).

Individual filopodia after transection from their parent growth cones have been used successf ully to quantify small, local changes in $\left[\mathrm{Ca}^{2+}\right]_{i}$ elicited by external stimuli (Davenport et al., 1993). Using a laser scissors system, we surgically isolated individual filopodia from growth cones loaded with fura-2AM $(5 \mu \mathrm{M})$, transferred them to the $\mathrm{Ca}^{2+}$ imaging system, and determined $\left[\mathrm{Ca}^{2+}\right]_{\mathrm{i}} 30 \mathrm{~min}$ after laser-assisted transection (Figs. 4, 5). Only isolated filopodia with stable $\left[\mathrm{Ca}^{2+}\right]_{\mathrm{i}}$ and intact morphology were included in our study. Also, we substituted soluble LN for LNcoated beads because our $\mathrm{Ca}^{2+}$ imaging system was not equipped with laser tweezers, so an application of LN-coated beads to isolated filopodia was impossible. Of 22 isolated filopodia with intact morphology, 12 filopodia exhibited stable resting $\left[\mathrm{Ca}^{2+}\right]_{\mathrm{i}}$ $<100 \mathrm{~nm}(83 \pm 6 \mathrm{~nm}, n=12)$. The remaining 10 isolated filopodia also had stable resting $\left[\mathrm{Ca}^{2+}\right]_{\mathrm{i}}$ that was $>100 \mathrm{~nm}$, ranging from 150 to $400 \mathrm{~nm}$. Of the 12 isolated filopodia with resting $\left[\mathrm{Ca}^{2+}\right]_{\mathrm{i}}$ $<100 \mathrm{nM}$, nine reacted with a rapid rise of $\left[\mathrm{Ca}^{2+}\right]_{\mathrm{i}}(+73 \pm 11 \mathrm{nM}$; $n=12 ; p<0.001)$ on the addition of soluble LN (20 $\mu \mathrm{l}, 20$ $\mu \mathrm{g} / \mathrm{ml}$ ), peaking at $156 \pm 14 \mathrm{~nm}$ (Figs. 5, 7a). As our control, bath application of FN $(20 \mu \mathrm{l}, 20 \mu \mathrm{g} / \mathrm{ml})$ had no effect on $\left[\mathrm{Ca}^{2+}\right]_{\mathrm{i}}$ in transected filopodia with resting $\left[\mathrm{Ca}^{2+}\right]_{\mathrm{i}}<100 \mathrm{~nm}$ (Fig. $7 a$ ). Nevertheless, the 10 isolated filopodia with resting $\left[\mathrm{Ca}^{2+}\right]_{i}>100$ $\mathrm{nM}$ also responded with rapid changes in $\left[\mathrm{Ca}^{2+}\right]_{\mathrm{i}}(+118 \pm 23 \mathrm{nM}$; $n=10)$ to an addition of soluble LN (Fig. 7b).

Taken together, surgically isolated filopodia react to the addition of soluble $\mathrm{LN}$ with an immediate, rapid rise of $\left[\mathrm{Ca}^{2+}\right]_{\mathrm{i}}$ irrespective of the current resting $\left[\mathrm{Ca}^{2+}\right]_{\mathrm{i}}$. This finding, combined with our pharmacological data, suggests that LN-mediated growth cone turning requires an influx of extracellular $\mathrm{Ca}^{2+}$ most likely occurring into filopodia with LN contact.

\section{A sustained rise of $\left[\mathrm{Ca}^{2+}\right]_{i}$ in growth cones subsequent to a pause at LN-coated beads is associated with increased rates of outgrowth}

In the standard assay, growth cones responded to transient LNcoated bead contact with sustained, increased rates of outgrowth. 

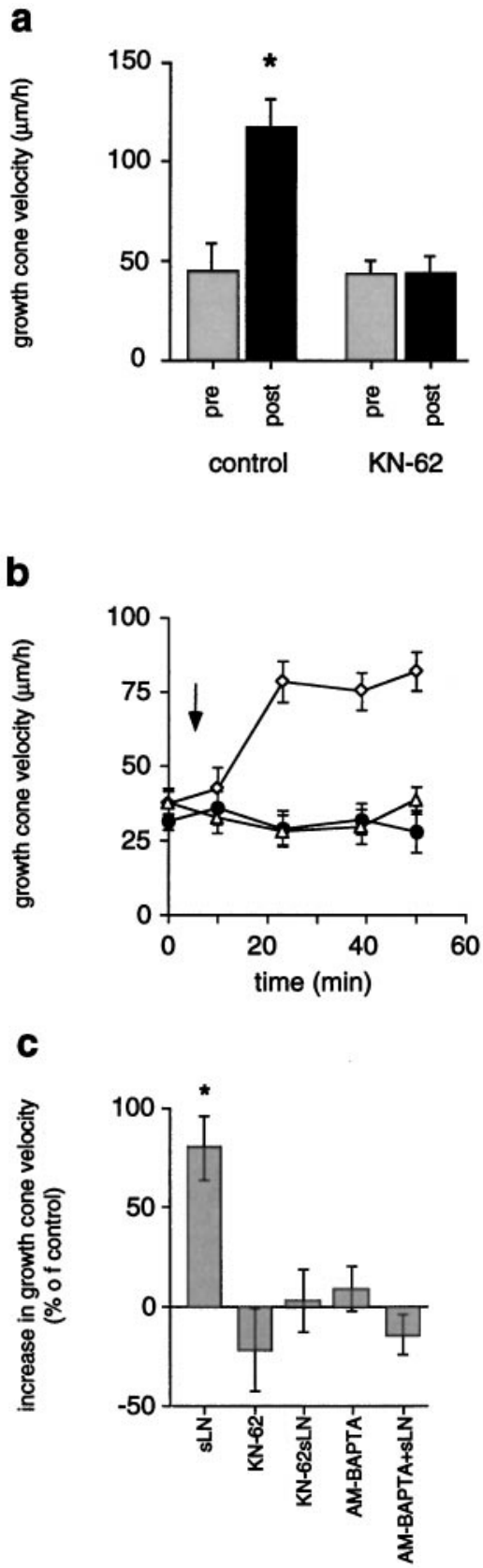

Figure 3. CaM-kinase II regulates growth cone motility signaled by LN via increasing rates of outgrowth. $a$, In the standard assay, growth cones advance with increased rates of outgrowth for considerable distances subsequent to a pause at $\mathrm{LN}$-coated beads $\left({ }^{*} p<0.001\right)$. Specific inhibition of CaM-kinase II with $2 \mu \mathrm{M}$ KN-62 prevents this response ( pre, before contact; post, after contact). $b$, The addition of soluble LN to DRG growth cones (FN substrate) stimulates increased rates of outgrowth (open diamonds), whereas the presence of $2 \mu \mathrm{M} \mathrm{KN}$ 62 (open triangles) blocks this effect. Outgrowth on $\mathrm{FN}$ in the absence of LN is not significantly affected by $\mathrm{KN}-62$ (filled circles). An arrow marks the time point of the addition of $\mathrm{LN}$ and/or $\mathrm{KN}-62(t=10$ min). $c$, A preceding $\mathrm{Ca}^{2+}$ signal is essential for CaM-kinase IIdependent increases in rates of outgrowth stimulated by LN. Soluble LN $(s L N)$ induces an increase of rates of outgrowth by $+80 \pm 16 \%$ $\left({ }^{*} p<0.001\right)$. Blocking CaM-kinase II $(2 \mu \mathrm{M} K N-62)$ inhibits the growth-promoting effect of soluble $\mathrm{LN}(K N-62+s L N)$ without affecting growth cone advance on $\mathrm{FN}(K N-62)$. Also, chelating rises in $\left[\mathrm{Ca}^{2+}\right]_{\mathrm{i}}(A M-B A P T A+s L N)$ negate increased growth cone motility in response to soluble $\mathrm{LN}$ without altering growth cone advance on FN (AM-BAPTA).

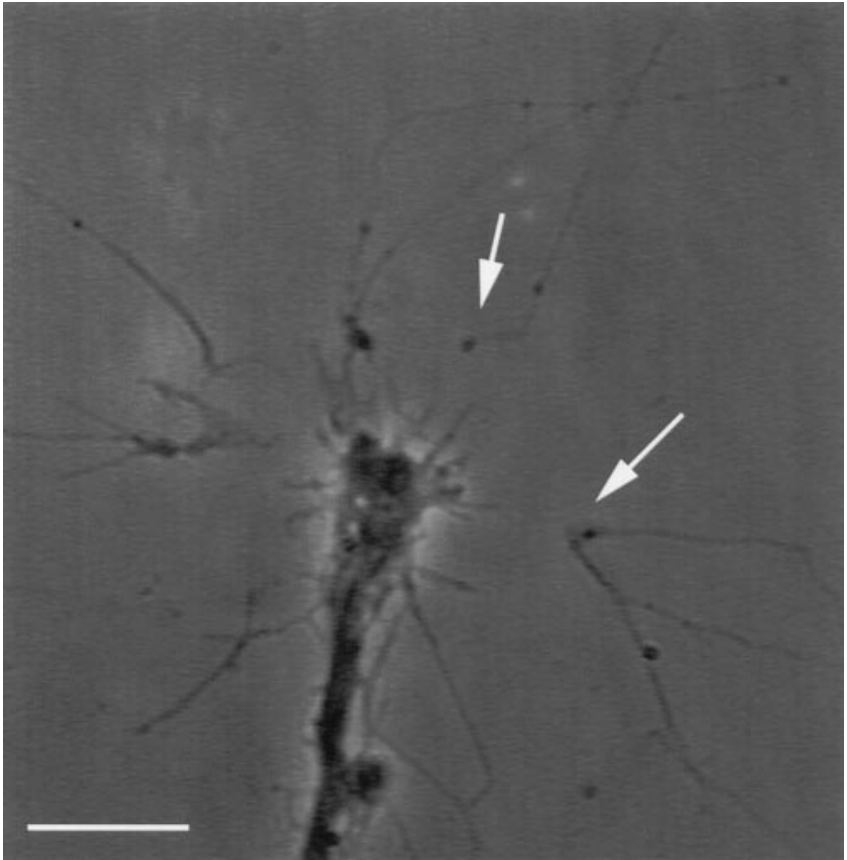

Figure 4. Surgical isolation of individual filopodia. Isolated filopodia (arrows), often 20-30 $\mu \mathrm{m}$ long, exhibit intact morphology after laserassisted transection from their parent, fura-loaded growth cones. A large gap forms between an isolated filopodium and parent growth cone after laser-assisted transection (arrows). This gap results from a retraction of each of the cut ends. This phase picture of a fura-loaded growth cone $(5$ $\mu \mathrm{M}$ fura-2AM) was taken $20 \mathrm{~min}$ after the surgical isolation of filopodia. Scale bar, $10 \mu \mathrm{m}$.

Previous findings have demonstrated that growth cone motility is very sensitive even to subtle changes in $\left[\mathrm{Ca}^{2+}\right]_{i}$ (Kater and Mills, 1991). Therefore, we measured $\left[\mathrm{Ca}^{2+}\right]_{\mathrm{i}}$ during the entire series of stereotypic growth cone responses, including the period of increased rates of outgrowth.

We found that, subsequent to a pause at LN-coated beads, growth cones exhibited small but significant rises of $\left[\mathrm{Ca}^{2+}\right]_{i}$ $(83 \pm 2 \%, n=20$ of $24 ; p<0.0001)$, peaking at $105 \pm 6 \mathrm{nM}$, as compared with average resting $\left[\mathrm{Ca}^{2+}\right]_{\mathrm{i}}$ of $42 \pm 2 \mathrm{nM}(n=14)$ (Fig. $6 a$ ). $\left[\mathrm{Ca}^{2+}\right]_{\mathrm{i}}$ remained elevated, whereas growth cones advanced considerable distances beyond LN-coated beads (72 \pm $7 \%$ of growth cones investigated, $n=17$ of 24). Most importantly, rises of $\left[\mathrm{Ca}^{2+}\right]_{\mathrm{i}}$ occurred with a distinct delay of $28 \pm 3 \mathrm{~min}(n=$ 24) after growth cones first contacted LN-coated beads (Fig. 8a) and strongly correlated in time with the period of increased rates of outgrowth (delay $>20 \mathrm{~min}$ after first LN-coated bead contact). In control experiments no changes in $\left[\mathrm{Ca}^{2+}\right]_{i}$ were observed in growth cones that encountered FN-coated beads on an FN substrate.

This delayed, sustained $\mathrm{Ca}^{2+}$ signal could have been temporally distinct from the $\mathrm{Ca}^{2+}$ influx into filopodia induced on $\mathrm{LN}$ contact or simply a trivial consequence of the standard assay: a slow but steady elevation of $\left[\mathrm{Ca}^{2+}\right]_{\mathrm{i}}$ initiated by filopodial contact to $\mathrm{LN}$-coated beads and a concomitant approach to LN-coated beads by the growth cone. To test these two alternatives, we selectively measured rises of $\left[\mathrm{Ca}^{2+}\right]_{\mathrm{i}}$ in growth cones contacting LN-coated beads only with their body and having no previous contact with filopodia, thus eliminating the approach phase to LN-coated beads (Fig. $8 b$ ). Here, LN-induced rises of $\left[\mathrm{Ca}^{2+}\right]_{i}$ were characterized by (1) a delay of $29 \pm 6$ min occurring after 

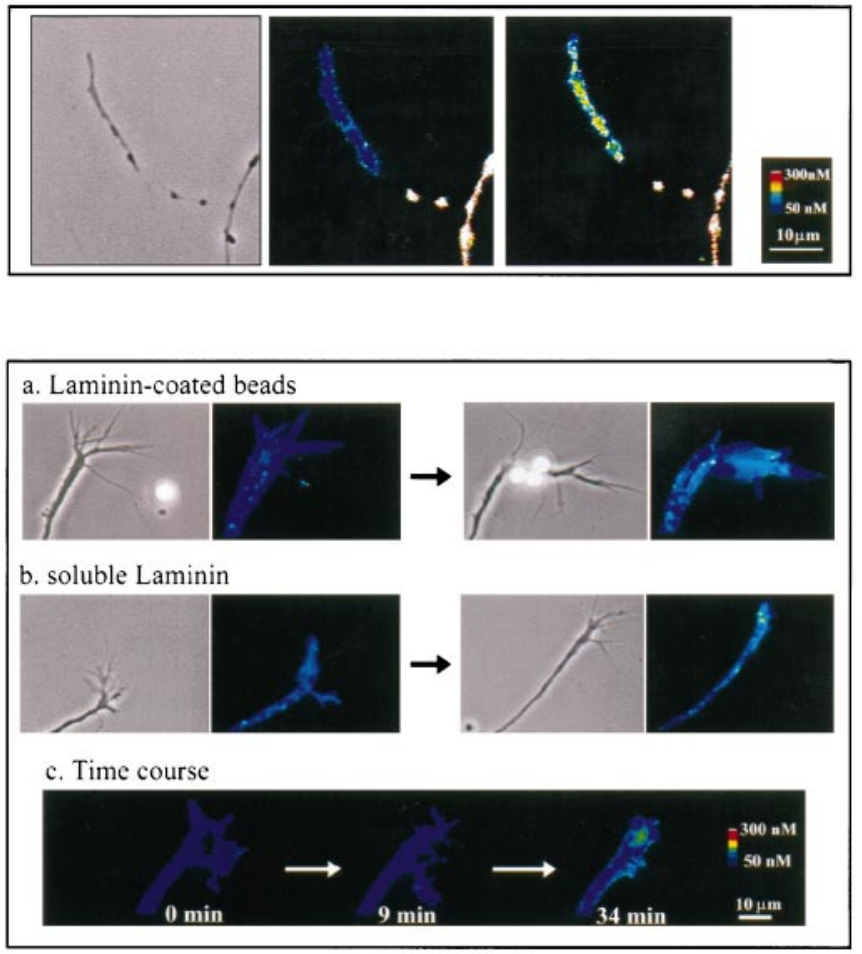

Figure 5. Top. Soluble LN induces an elevation of $\left[\mathrm{Ca}^{2+}\right]_{\mathrm{i}}$ in surgically isolated filopodia. Using laser scissors, we surgically isolated individual filopodia from growth cones loaded previously with $5 \mu \mathrm{M}$ fura-2AM for 35 min (phase picture, left panel). Fura images were acquired $30 \mathrm{~min}$ after surgical isolation, and only filopodia with stable resting $\left[\mathrm{Ca}^{2+}\right]_{\mathrm{i}}$ were considered for further experiments (middle panel). Damaged filopodia generally had $\left[\mathrm{Ca}^{2+}\right]_{\mathrm{i}}$ levels $>1 \mu \mathrm{M}$. Bath application of $20 \mu \mathrm{l}$ of LN (20 $\mu \mathrm{g} / \mathrm{ml})$ stimulated an immediate rise of $\left[\mathrm{Ca}^{2+}\right]_{\mathrm{i}}$ determined 2 min after $\mathrm{LN}$ application (right panel). The color bar shows linear $\mathrm{Ca}^{2+}$ concentrations. Scale bar, $10 \mu \mathrm{M}$.

Figure 6. Bottom. LN induces a delayed, sustained rise of $\left[\mathrm{Ca}^{2+}\right]_{\mathrm{i}} \cdot a$, Long-term observation of fura-loaded growth cones during $\mathrm{LN}$-coated bead encounters reveals small but significant rises of $\left[\mathrm{Ca}^{2+}\right]_{i}$ in growth cones subsequent to a pause at $\mathrm{LN}$-coated beads. No $\mathrm{Ca}^{2+}$ signal is detectable on filopodial contact to LN-coated beads (left panel). After a pause at LN-coated beads, the growth cone continues to advance. During this phase fluorescent $\mathrm{Ca}^{2+}$ imaging reveals a delayed, sustained rise of $\left[\mathrm{Ca}^{2+}\right]_{\mathrm{i}}$ (right panel). The time difference between left and right panels is 24 min. $b$, The addition of soluble $\mathrm{LN}$ induces rises of $\left[\mathrm{Ca}^{2+}\right]_{\mathrm{i}}$ with characteristics similar to those induced by LN-coated beads. The left panel shows a growth cone immediately after the addition of soluble LN. Note that the growth cones exhibits resting $\left[\mathrm{Ca}^{2+}\right]_{\mathrm{i}}$. Significant increases in $\left[\mathrm{Ca}^{2+}\right]_{\mathrm{i}}$ become noticeable after $16 \mathrm{~min}$ (right panel). $c$, No gradual increase of $\left[\mathrm{Ca}^{2+}\right]_{\mathrm{i}}$ occurs on contact with LN-coated beads or with the addition of soluble $\mathrm{LN}$. $\left[\mathrm{Ca}^{2+}\right]_{\mathrm{i}}(t=9 \mathrm{~min})$ in growth cones during the delay phase is indistinguishable from resting $\left[\mathrm{Ca}^{2+}\right]_{\mathrm{i}}(t=0 \mathrm{~min})$. According to our criterion (see Materials and Methods), a rise of $\left[\mathrm{Ca}^{2+}\right]_{i}$ occurs 34 min after bath application of LN. Note that elevations in $\left[\mathrm{Ca}^{2+}\right]_{\mathrm{i}}$ in neurite shafts were smaller than $+20 \mathrm{nM}$, and no significance was assumed. The color bar shows linear $\mathrm{Ca}^{2+}$ concentrations. Scale bar, $10 \mu \mathrm{M}$.

the first contact of growth cone bodies to LN-coated beads, (2) an elevation of $\left[\mathrm{Ca}^{2+}\right]_{\mathrm{i}}$ peaking at $+103 \pm 7 \mathrm{~nm}(n=12$ of 17) (resting $\left.\left[\mathrm{Ca}^{2+}\right]_{\mathrm{i}}=42 \pm 2 \mathrm{nM}, n=14\right),(3)$ a temporal correlation with the period of increased rates of outgrowth, and (4) a sustained elevation of $\left[\mathrm{Ca}^{2+}\right]_{i}$, while growth cones advanced considerable distances beyond LN-coated beads. No changes in $\left[\mathrm{Ca}^{2+}\right]_{\mathrm{i}}$ were observed when $\mathrm{LN}$-coated beads directly contacted neurite shafts with no previous contact to either filopodia or growth cones (open triangles in Fig. $8 b$ ). Regardless of the mode
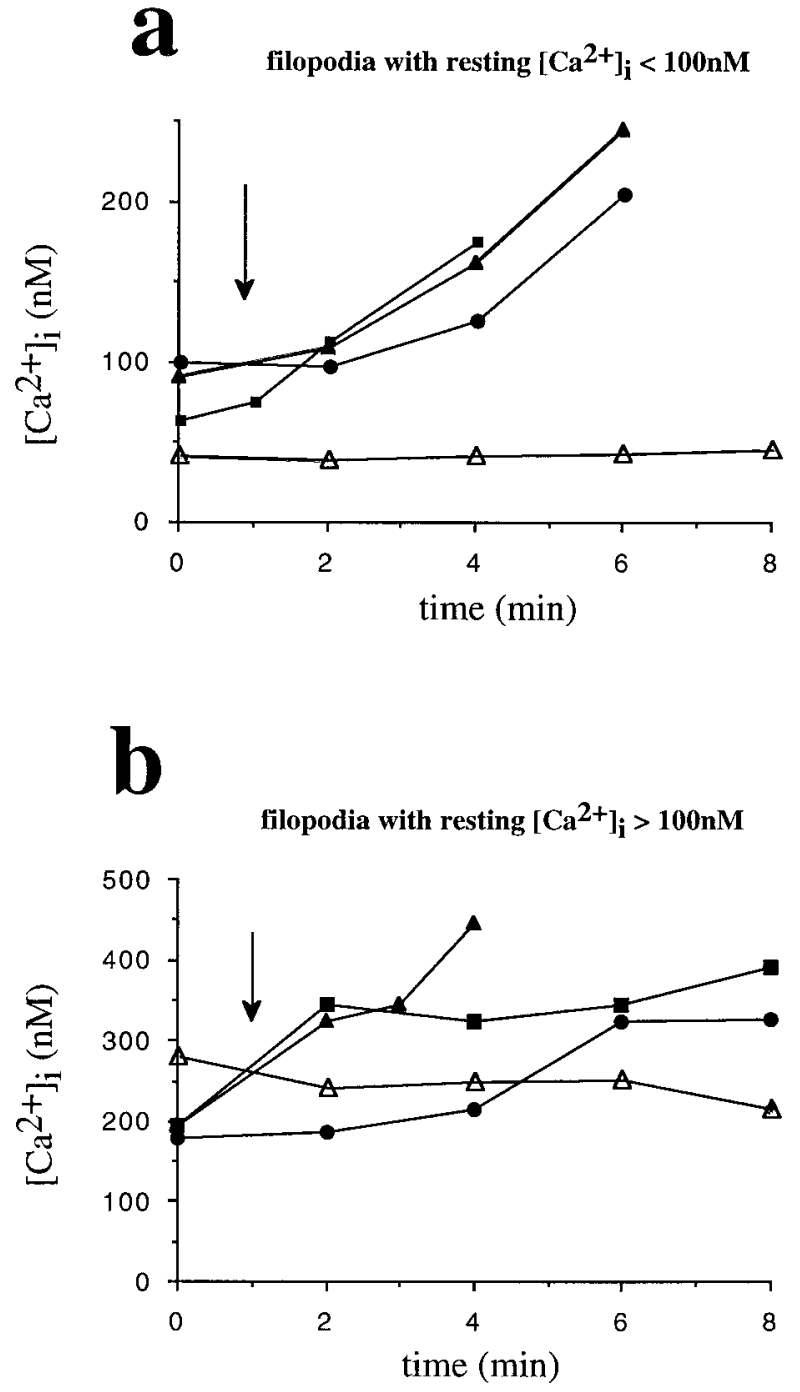

Figure 7. Soluble LN stimulates a rapid increase of $\left[\mathrm{Ca}^{2+}\right]_{\mathrm{i}}$ in surgically isolated filopodia. $a$, Filopodia with resting $\left[\mathrm{Ca}^{2+}\right]_{\mathrm{i}}<100 \mathrm{nM}$ responded with a rapid rise of $\left[\mathrm{Ca}^{2+}\right]_{\mathrm{i}}$ to bath-applied $\mathrm{LN}(20 \mu \mathrm{l}, 20 \mu \mathrm{g} / \mathrm{ml})$. LN was added at $t=2 \mathrm{~min}$ (arrow), and significant increases in $\left[\mathrm{Ca}^{2+}\right]_{\mathrm{i}}$ were measured at $t=4 \mathrm{~min}$. Three representative isolated filopodia are shown (filled symbols). Identical concentrations of soluble FN had no effect (open triangles). $b$, Filopodia with resting $\left[\mathrm{Ca}^{2+}\right]_{\mathrm{i}}>100 \mathrm{nM}$ also responded to soluble LN $(t=2 \mathrm{~min})$ with a rapid increase of $\left[\mathrm{Ca}^{2+}\right]_{\mathrm{i}}(t=4 \mathrm{~min})$. Data from three representative isolated filopodia are plotted ( filled symbols). As a control, the addition of soluble FN has no effect on $\left[\mathrm{Ca}^{2+}\right]_{\mathrm{i}}$ (open triangles). Substrate of neuronal culture $=\mathrm{FN}$.

of $\mathrm{LN}$ presentation, levels of $\left[\mathrm{Ca}^{2+}\right]_{\mathrm{i}}$ in growth cones during the delay phase (40 $\pm 2 \mathrm{nM}, n=26)$ were not significantly different from levels of $\left[\mathrm{Ca}^{2+}\right]_{\mathrm{i}}$ before any $\mathrm{LN}$ contact $\left(\right.$ resting $\left[\mathrm{Ca}^{2+}\right]_{\mathrm{i}}=$ $42 \pm 2 \mathrm{~nm}, n=14)$. These data demonstrated that the delayed, sustained $\mathrm{Ca}^{2+}$ signal was not simply a trivial consequence of our standard assay but a temporally distinct event.

Soluble laminin $(20 \mu \mathrm{l}, 20 \mu \mathrm{g} / \mathrm{ml})$ induced rises of $\left[\mathrm{Ca}^{2+}\right]_{\mathrm{i}}$ in growth cones with characteristics indistinguishable from those described for the delayed, sustained $\mathrm{Ca}^{2+}$ signal induced by LN-coated bead contact (Figs. $6 b, 8 c$ ). Rises of $\left[\mathrm{Ca}^{2+}\right]_{\mathrm{i}}$ peaked at $142 \pm 11 \mathrm{~nm}(+94 \pm 11 \mathrm{nM}, n=12$ of $14 ; p<0.001)$ as compared with resting $\left[\mathrm{Ca}^{2+}\right]_{\mathrm{i}}(46 \pm 8 \mathrm{nM}, n=12)$ and occurred with a distinct delay of $20 \pm 4 \mathrm{~min}(n=13)$ after the addition of soluble LN. Elevated levels of $\left[\mathrm{Ca}^{2+}\right]_{\mathrm{i}}$ were sustained and correlated with 
$\mathbf{a}$

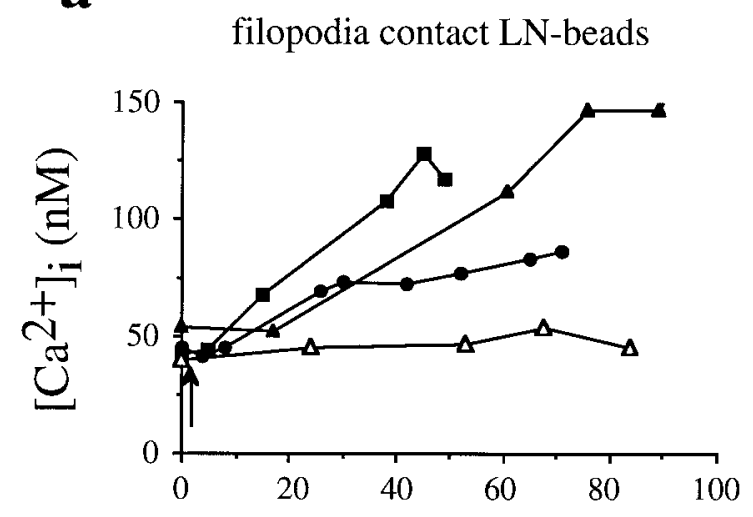

b growth cone bodies contact LN-beads
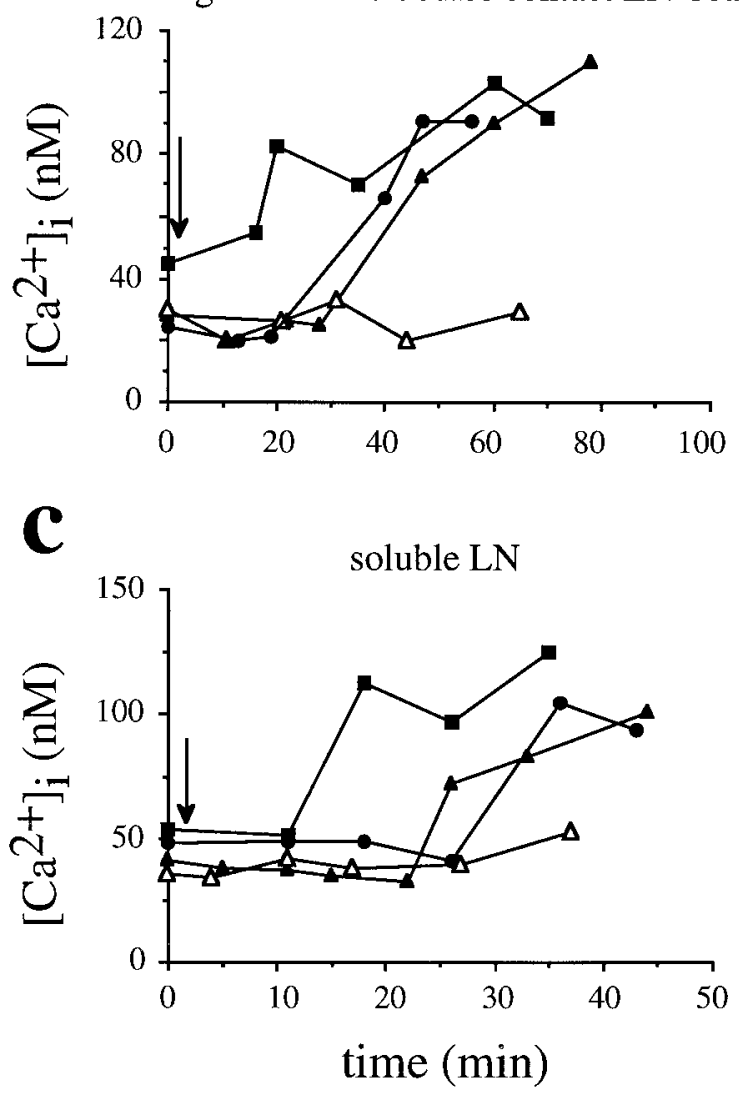

Figure 8. LN stimulates a second, sustained rise of $\left[\mathrm{Ca}^{2+}\right]_{\mathrm{i}}$ that is temporally distinct from the $\mathrm{Ca}^{2+}$ influx in filopodia contacting LN. $a$, Time course of changes in $\left[\mathrm{Ca}^{2+}\right]_{\mathrm{i}}$ are plotted for three individual growth cones advancing on FN after encountering LN-coated beads with their filopodia ( filled symbols). The arrow marks the time point when growth cones first contacted LN-coated beads. $\left[\mathrm{Ca}^{2+}\right]_{\mathrm{i}}$ increases with a distinct delay after contact. LN-coated beads elicit no rise of $\left[\mathrm{Ca}^{2+}\right]_{\mathrm{i}}$ if contacting a neurite shaft (open triangles). $b$, Growth cones with no previous filopodial contact to $\mathrm{LN}$-coated beads also exhibit delayed rises of $\left[\mathrm{Ca}^{2+}\right]_{\mathrm{i}}($ filled symbols $)$. This suggests that this delay is not a trivial consequence of growth cones approaching LN-coated beads after filopodial contact, together with a gradual rise of $\left[\mathrm{Ca}^{2+}\right]_{\mathrm{i}}$. Note that $\left[\mathrm{Ca}^{2+}\right]_{\mathrm{i}}$ remained at resting levels for $>20$ min. $c$, Soluble LN induces a delayed, sustained increase in $\left[\mathrm{Ca}^{2+}\right]_{\mathrm{i}}$ with similar characteristics to those observed for LN-coated beads. Measurements of three representative growth cones are shown ( filled symbols). Growth cones advancing on FN do not respond with changes in $\left[\mathrm{Ca}^{2+}\right]_{\mathrm{i}}$ on the addition of soluble FN (open triangles). increased rates of outgrowth detectable $15 \mathrm{~min}$ after the addition of soluble LN. As our controls, soluble FN (20 $\mu \mathrm{l}, 20 \mu \mathrm{g} / \mathrm{ml})$ had no effect on $\left[\mathrm{Ca}^{2+}\right]_{\mathrm{i}}\left(51 \pm 3 \mathrm{nM}, n=6\right.$; average resting $\left[\mathrm{Ca}^{2+}\right]_{\mathrm{i}}$ $=45 \pm 2 \mathrm{~nm}, n=6)$, and soluble $\mathrm{LN}$ caused no significant rises in $\left[\mathrm{Ca}^{2+}\right]_{\mathrm{i}}(36 \pm 3 \mathrm{nM}, n=8)$ in growth cones advancing on LN (average resting $\left[\mathrm{Ca}^{2+}\right]_{\mathrm{i}}=32 \pm 2 \mathrm{nM}, n=8$ ) (open triangles in Fig. $8 c$ ). A small number of growth cones advancing on LN responded to soluble $\mathrm{LN}$ with a positive rise in $\left[\mathrm{Ca}^{2+}\right]_{\mathrm{i}}(27 \%, n=$ 3 of 11) according to the criterion set (see Materials and Methods). However, we assumed no significance because $\left[\mathrm{Ca}^{2+}\right]_{\mathrm{i}}$ peaked at $50 \pm 5 \mathrm{~nm}$ and increased only by $+16 \pm 3 \mathrm{~nm}$.

Our results show that growth cones respond to a $\mathrm{LN}$ stimulus with a delayed, sustained rise of $\left[\mathrm{Ca}^{2+}\right]_{\mathrm{i}}$ irrespective of filopodial contact, direct growth cone body contact, or both, as in the case of soluble LN. This finding strongly suggests that the delayed, sustained $\mathrm{Ca}^{2+}$ signal is temporally (delay $>20 \mathrm{~min}$ ) and functionally (association with the period of increased rates of outgrowth) distinct from the first $\mathrm{Ca}^{2+}$ signal, which is characterized by a delay of $<2 \mathrm{~min}$ and by an association with growth cone turning.

\section{CaM-kinase II regulates the delayed, sustained rise in $\left[\mathrm{Ca}^{2+}\right]_{i}$}

We have identified a delayed, sustained rise of $\left[\mathrm{Ca}^{2+}\right]_{\mathrm{i}}$ in growth cones associated with the period of increased rates of outgrowth, both resulting from a transient contact to $\mathrm{LN}$-coated beads. We have shown previously that inhibition of CaM-kinase II abolished the period of increased rates of outgrowth. Thus, we examined whether the delayed, sustained rise of $\left[\mathrm{Ca}^{2+}\right]_{\mathrm{i}}$ was sensitive to CaM-kinase II inhibition.

The addition of soluble LN (20 $\mu \mathrm{l}, 20 \mu \mathrm{g} / \mathrm{ml})$ significantly shifted the distribution of $\left[\mathrm{Ca}^{2+}\right]_{\mathrm{i}}$ in a population of growth cones to higher levels of $\left[\mathrm{Ca}^{2+}\right]_{\mathrm{i}}$ according to the criterion set (see Materials and Methods) (Fig. 9a). Average resting $\left[\mathrm{Ca}^{2+}\right]_{\mathrm{i}}$ of $48 \pm 3 \mathrm{nM}$ was determined before $\mathrm{LN}$ addition, whereas $\left[\mathrm{Ca}^{2+}\right]_{\mathrm{i}}$ peaked at $111 \pm 13 \mathrm{~nm}(n=17$ of 19$)$ after the addition of LN. In the presence of $\mathrm{KN}-62$, soluble $\mathrm{LN}$ induced no shift in the distribution of $\left[\mathrm{Ca}^{2+}\right]_{\mathrm{i}}$ (Fig. $9 a$ ). Resting levels of $\left[\mathrm{Ca}^{2+}\right]_{\mathrm{i}}$ in the presence of $\mathrm{KN}-62(47 \pm 3 \mathrm{nM})$ were not affected, as opposed to levels of $\left[\mathrm{Ca}^{2+}\right]_{\mathrm{i}}$ in the absence of KN-62 (48 $\left.\pm 3 \mathrm{nM}\right)$. According to the criterion set (see Materials and Methods), 33\% ( $n=7$ of 21 ) of growth cones exhibited a statistically significant rise in $\left[\mathrm{Ca}^{2+}\right]_{\mathrm{i}}(t$ test $)$. However, we assumed no true significance because the actual net change in $\left[\mathrm{Ca}^{2+}\right]_{\mathrm{i}}$ was only $10 \pm 3 \mathrm{~nm}$.

Previous studies had shown that inhibition of PKC blocked all growth cone responses in the standard assay subsequent to growth cone turning (Kuhn et al., 1995). Therefore, we examined the effect of PKC inhibition on the delayed, sustained rise of $\left[\mathrm{Ca}^{2+}\right]_{\mathrm{i}}$. The presence of $10 \mathrm{~nm}$ bisindolylmaleimide (BIS), a specific PKC inhibitor (Toullec et al., 1991), clearly blocked an LN-stimulated shift in the distribution of $\left[\mathrm{Ca}^{2+}\right]_{\mathrm{i}}$ in growth cones advancing on FN, whereas $10 \mathrm{~nm}$ BIS had no effect on the distribution of resting levels of $\left[\mathrm{Ca}^{2+}\right]_{\mathrm{i}}$ as compared with control (Fig. 9b). In summary, KN-62 and BIS both blocked the delayed, sustained change in $\left[\mathrm{Ca}^{2+}\right]_{\mathrm{i}}$ in growth cones stimulated by soluble LN (Fig. 9c). The effect of the CaM-inhibitor, FPC, could not be assessed because resting $\left[\mathrm{Ca}^{2+}\right]_{\mathrm{i}}$ was affected by this inhibitor. With respect to these findings, CaM-kinase II, PKC, and potentially $\mathrm{Ca}^{2+} / \mathrm{CaM}$ are involved in regulating the delayed, sustained $\mathrm{Ca}^{2+}$ signal in growth cones stimulated by $\mathrm{LN}$. 

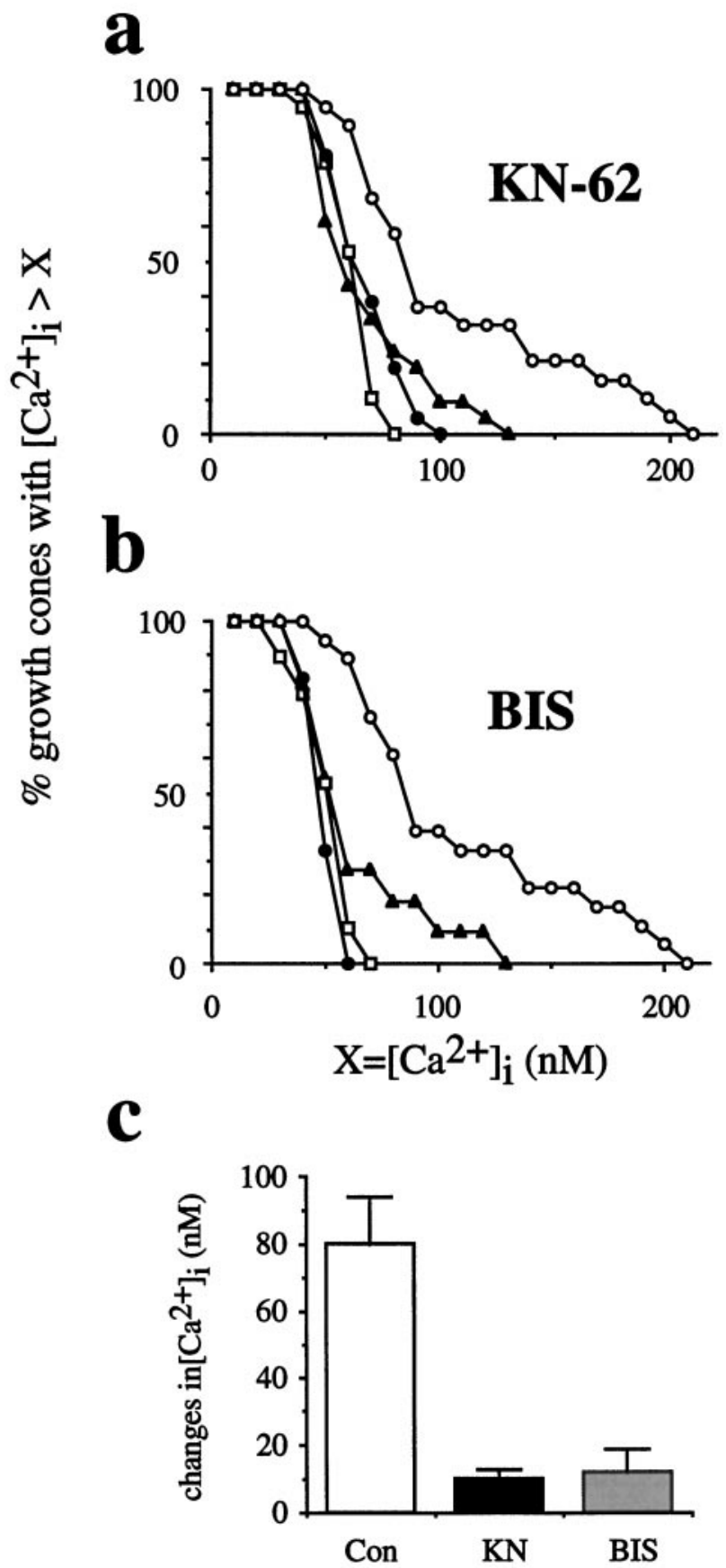

Figure 9. CaM-kinase II and PKC regulate the delayed, sustained rise of $\left[\mathrm{Ca}^{2+}\right]_{\mathrm{i}} \cdot a$, Inhibition of CaM-kinase II $(K N-62)$ blocks $\mathrm{LN}$-induced rises in $\left[\mathrm{Ca}^{2+}\right]_{\mathrm{i}}$. The distribution of $\left[\mathrm{Ca}^{2+}\right]_{\mathrm{i}}$ of a population of growth cones is plotted against $\left[\mathrm{Ca}^{2+}\right]_{\mathrm{i}}$. Open squares illustrate the distribution of resting $\left[\mathrm{Ca}^{2+}\right]_{\mathrm{i}}$ in growth cones advancing on FN. After the addition of soluble $\mathrm{LN}$, a large number of growth cones respond with rises of $\left[\mathrm{Ca}^{2+}\right]_{i}$, and the distribution of $\left[\mathrm{Ca}^{2+}\right]_{\mathrm{i}}$ shifts to higher $\left[\mathrm{Ca}^{2+}\right]_{\mathrm{i}}$ (open circles). A presence of $2 \mu \mathrm{M} \mathrm{KN}-62$ negates the shift in the distribution of $\left[\mathrm{Ca}^{2+}\right]_{\mathrm{i}}$ expected on the addition of soluble LN (filled triangles). The distribution of resting $\left[\mathrm{Ca}^{2+}\right]_{\mathrm{i}}$ is unaffected by $\mathrm{KN}-62$ (filled circles). $b$, In the presence of $10 \mathrm{~nm}$ bisindolylmaleimide $(B I S)$, a specific PKC inhibitor, the distribution of resting $\left[\mathrm{Ca}^{2+}\right]_{\mathrm{i}}$ ( filled circles) is identical to that under control conditions (open squares). However, BIS blocks the expected change in the distribution of $\left[\mathrm{Ca}^{2+}\right]_{\mathrm{i}}$ in growth cones on the addition of soluble LN (closed triangles). $c$, The change in $\left[\mathrm{Ca}^{2+}\right]_{\mathrm{i}}$ induced by soluble $\mathrm{LN}$ is shown as a function of the inhibitors that are present. Inhibition of both CaM-kinase II [KN-62 $(K N)]$ and PKC [bisindolylmaleimide $(B I S)]$ negates $\mathrm{LN}$-induced rises in $\left[\mathrm{Ca}^{2+}\right]_{\mathrm{i}}$. Con, Control conditions.

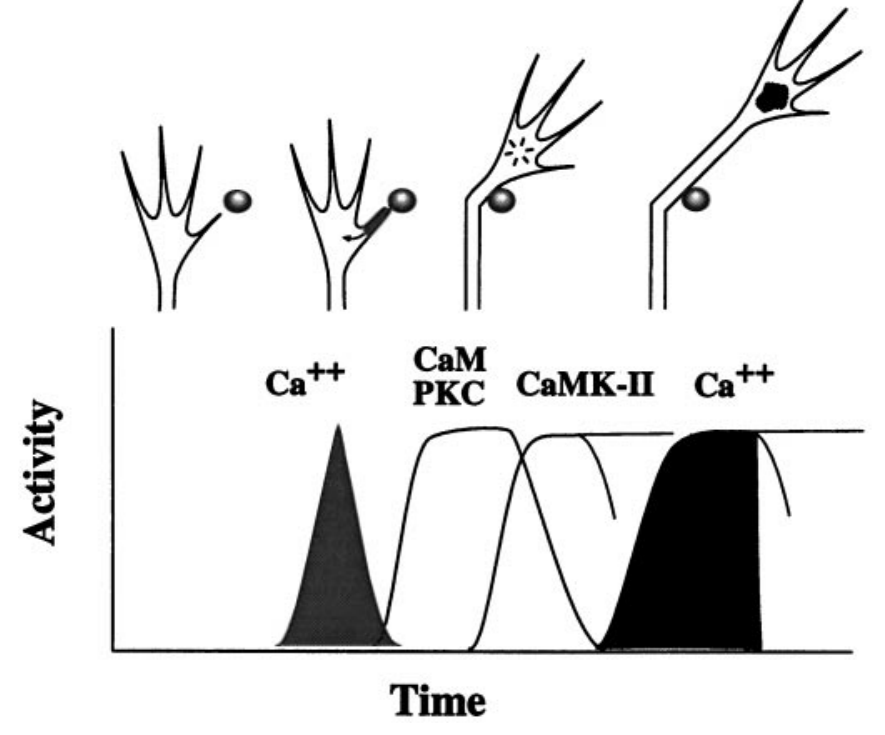

Figure 10. Proposed mechanism underlying LN-mediated growth cone guidance in vitro. Our results suggest that guidance instructions provided by $\mathrm{LN}$-coated beads activate a signaling mechanism composed of two temporally and functionally distinct $\mathrm{Ca}^{2+}$ signals that are linked sequentially by $C a M, P K C$, and CaM-kinase II (CaMK-II). Growth cones establish contact to $\mathrm{LN}$-coated beads with individual filopodia. This adhesion event stimulates in an influx of extracellular $\mathrm{Ca}^{2+}$, presumably at adhesion sites between filopodia and LN-coated beads, resulting in a rise of $\left[\mathrm{Ca}^{2+}\right]_{\mathrm{i}}$ (shading adherent filopodia). This early $\mathrm{Ca}^{2+}$ signal is required for growth cone turning, together with an activation of downstream targets (arrow), including CaM and PKC (marked inside the growth cone). This is followed by a $\mathrm{Ca}^{2+} / \mathrm{CaM}$-dependent activation of CaM-kinase II, which regulates both the delayed and sustained rise of $\left[\mathrm{Ca}^{2+}\right]_{\mathrm{i}}$ associated with the period of increased rates of outgrowth (dark shading inside the growth cone).

\section{DISCUSSION}

This in vitro study provided evidence that LN-mediated growth cone guidance, a stereotypic series of changes in growth cone behavior and morphology, could be attributed to two temporally and functionally distinct $\mathrm{Ca}^{2+}$ signals linked by a sequential signaling cascade composed of $\mathrm{PKC}, \mathrm{CaM}$, and CaM-kinase II (Fig. 10).

\section{$\mathrm{Ca}^{2+}$ signaling in filopodia}

Growth cone guidance in vivo and in vitro, irrespective of the attractive or repulsive nature of environmental cues, depends on the enormous sensory capacity of individual filopodia (O'Connor et al., 1990; Chien et al., 1993; Fan and Raper, 1995; Li et al., 1996) (for review, see Kater and Rehder, 1995). Recently, it has been shown that filopodia are even essential for growth cone guidance by diff usible cues (Zheng et al., 1996). In our standard assay, adhesion of individual filopodia to LN-coated beads induced growth cone redirection. Although our pharmacological approach indicated an influx of extracellular $\mathrm{Ca}^{2+}$ required for LN-mediated turning, fluorescent $\mathrm{Ca}^{2+}$ imaging revealed no change in $\left[\mathrm{Ca}^{2+}\right]_{i}$ either in attached filopodia or in parent growth cones. In principle, pharmacological inhibition of growth cone turning could have resulted indirectly from a significant decrease of resting $\left[\mathrm{Ca}^{2+}\right]_{\mathrm{i}}$ in advancing growth cones. However, several lines of evidence speak against this alternative. Growth cones loaded with fura-2 displayed a similar series of stereotypic behavior in the standard assay, although fura- 2 does affect resting $\left[\mathrm{Ca}^{2+}\right]_{\mathrm{i}}$. A significant decrease of resting $\left[\mathrm{Ca}^{2+}\right]_{\mathrm{i}}$ should attenu- 
ate growth cone migration (Kater and Mills, 1991), but our pharmacological conditions had no effect on growth cone advance on FN (Table 1). Instead, higher inhibitor concentrations were detrimental for advancing growth cones. In addition, resting $\left[\mathrm{Ca}^{2+}\right]_{\mathrm{i}}$ in DRG neurons remained stable at nominal zero extracellular $\mathrm{Ca}^{2+}$ and in the presence of $\mathrm{Ni}^{2+}$ (Gomez et al., 1995) or with intracellular BAPTA $\left(K_{\mathrm{D}}=100-3600 \mu \mathrm{M}\right)$ (Tymianski et al., 1994). These arguments strongly favored a direct pharmacological inhibition of growth cone turning in the standard assay. We postulated that LN contact induced an influx of extracellular $\mathrm{Ca}^{2+}$ that was masked in attached filopodia. It was conceivable that this $\mathrm{Ca}^{2+}$ influx occurred in filopodia with LN contact.

Filopodia possess a relatively large surface area-to-volume ratio; consequently, a rise of $\left[\mathrm{Ca}^{2+}\right]_{\mathrm{i}} \leq 100 \mathrm{nM}$ is composed of only a small number of $\mathrm{Ca}^{2+}$ ions (Davenport et al., 1993). Taking into account the small number of $\mathrm{Ca}^{2+}$ ions and the spatial restriction of the LN-stimulus in the bead assay, we theorized that the masking of a $\mathrm{Ca}^{2+}$ signal in attached filopodia could result from (1) extrusion of $\mathrm{Ca}^{2+}$ ions into the extracellular space, (2) sequestration of $\mathrm{Ca}^{2+}$ ions by $\mathrm{Ca}^{2+}$ binding proteins or into intracellular stores, and/or (3) a dilution of $\mathrm{Ca}^{2+}$ ions after rapid diff usion into parent growth cones. Extrusion of $\mathrm{Ca}^{2+}$ ions into the extracellular space by $\mathrm{Ca}^{2+}-\mathrm{ATPase}$ is one major regulatory mechanism in neuronal growth cones (Werth et al., 1996). CaM could play a critical role in $\mathrm{Ca}^{2+}$-dependent signaling mechanisms because it is a major intracellular receptor for $\mathrm{Ca}^{2+} \cdot \mathrm{CaM}$ binds significant amounts of $\mathrm{Ca}^{2+}$ at concentrations slightly above resting $\left[\mathrm{Ca}^{2+}\right]_{\mathrm{i}}$ (James et al., 1995) and is abundant in filopodia (Letourneau et al., 1994). Relevant to this study, CaM inhibition blocked all growth cone responses after filopodial adhesion. VanBerkum and Goodman (1995) have demonstrated that the expression of inactive $\mathrm{CaM}$ mutants resulted in severe growth cone pathfinding errors, and focal inactivation of calcineurin, a CaM-dependent phosphatase, caused asymmetric retraction of filopodia (Chang et al., 1995).

Surgically isolated filopodia have been used successfully to demonstrate changes in $\left[\mathrm{Ca}^{2+}\right]_{\mathrm{i}}$ in individual filopodia despite the nonphysiological nature of the experiment (Davenport et al., 1993, 1996). We measured a rapid accumulation of $\mathrm{Ca}^{2+}$ in surgically isolated filopodia from chick DRG growth cones almost immediately after the application of soluble LN. This unmasking of an $\mathrm{LN}$-stimulated $\mathrm{Ca}^{2+}$ influx could be attributed either to an incapacity of $\mathrm{Ca}^{2+}$ extrusion into the extracellular space because of a lack of ATP supply from mitochondria in the parent growth cone (Werth et al., 1996) and/or to a saturation of $\mathrm{Ca}^{2+}$ binding proteins. Conclusively, proper engagement of $\mathrm{Ca}^{2+}$ clearing mechanisms in filopodia would require, at least to some extent, a physically intact connection between filopodia and the parent growth cone. Furthermore, it is reasonable that LN-coated beads elicit a similar, however masked, $\mathrm{Ca}^{2+}$ influx in adhering filopodia in regard to the results obtained with soluble $\mathrm{LN}$ in isolated filopodia and our pharmacological data in the standard assay.

\section{$\mathrm{Ca}^{2+}$ signals, CaM-kinase II activity, and their effects on growth cone motility}

Rises in $\left[\mathrm{Ca}^{2+}\right]_{\mathrm{i}}$ can induce a variety of growth cone responses from the inhibition of motility (Haydon et al., 1984; Robson and Burgoyne, 1989; Fields et al., 1993) to the promotion of motility (Holliday and Spitzer, 1990; Bedlack et al., 1992). Normal growth cone function depends on an optimal range of $\left[\mathrm{Ca}^{2+}\right]_{i}$ (alMohanna et al., 1992), whereas changes in $\left[\mathrm{Ca}^{2+}\right]_{\mathrm{i}}$ above or below this optimal range inhibit neurite outgrowth (Mattson and Kater, 1987; Kater and Mills, 1991).

In our experiments, the delayed, sustained $\mathrm{Ca}^{2+}$ signal was small in magnitude and correlated in time with increased rates of outgrowth. This implied that LN promoted growth cone motility via a small rise in $\left[\mathrm{Ca}^{2+}\right]_{\mathrm{i}} \cdot \mathrm{Ca}^{2+}$ signals in neurons stimulated by extracellular matrix (ECM) molecules have been described by Bixby et al. (1994) and Gomez et al. (1995), whereas others have proposed $\mathrm{Ca}^{2+}$-independent mechanisms (Campenot and Draker, 1989; Williams et al., 1992). In many non-neuronal cells, ECM-dependent adhesion, motility, and chemotaxis are associated with $\mathrm{Ca}^{2+}$ signals (for review, see Sjaastad and Nelson, 1997). In our hands, the acute addition of LN to cultured DRG neurons elicited small but significant rises of $\left[\mathrm{Ca}^{2+}\right]_{\mathrm{i}}$ in growth cones. Paradoxically, growth cones on a FN or a LN substratum exhibited resting levels of $\left[\mathrm{Ca}^{2+}\right]_{i}$ although $\mathrm{Ca}^{2+}$ chelators and general $\mathrm{Ca}^{2+}$ channel inhibitors reduced growth cone advance, thus indicating an essential tonic $\mathrm{Ca}^{2+}$ influx (Bixby at al., 1994). A similar discrepancy between acute versus tonic $\mathrm{Ca}^{2+}$ influx had been reported for $\mathrm{L} 1, \mathrm{NCAM}$, and $N$-cadherin. Growth cone advance on these substrates depended on a tonic $\mathrm{Ca}^{2+}$ influx through voltage-gated $\mathrm{L}$ - and $\mathrm{N}$-type $\mathrm{Ca}^{2+}$ channels (Doherty et al., 1991; Williams et al., 1992), but $\left[\mathrm{Ca}^{2+}\right]_{\mathrm{i}}$ remained at resting levels (Harper et al., 1994). Instead, acute activation of L1 or NCAM induced rises of $\left[\mathrm{Ca}^{2+}\right]_{\mathrm{i}}$ clearly above resting $\left[\mathrm{Ca}^{2+}\right]_{\mathrm{i}}$ (Schuch et al., 1989; Von Bohlen und Halbach et al., 1992). In conclusion, tonic stimuli apparently affected rates of $\mathrm{Ca}^{2+}$ cycling rather than steady-state levels of $\left[\mathrm{Ca}^{2+}\right]_{\mathrm{i}}$ (Harper et al., 1994).

Three types of LN applications were tested to determine conclusively whether the delayed, sustained $\mathrm{Ca}^{2+}$ was a trivial consequence of our LN-coated bead assay, i.e., a gradually increasing $\mathrm{Ca}^{2+}$ signal initiated by filopodial contact concomitant with a growth cone approach toward LN beads, or a temporally distinct event. Irrespective of the mode of LN presentation, a distinct delay phase preceded the sustained rise of $\left[\mathrm{Ca}^{2+}\right]_{\mathrm{i}}: 28 \pm 3 \mathrm{~min}$ after first filopodial contact in the standard assay, $29 \pm 6$ min after LN contact to growth cone bodies without previous filopodial contact, and $20 \pm 4 \mathrm{~min}$ after the addition of soluble LN. During the delay phase under each test condition, levels of $\left[\mathrm{Ca}^{2+}\right]_{i}$ were indistinguishable from resting $\left[\mathrm{Ca}^{2+}\right]_{\mathrm{i}}$. Therefore, the delayed, sustained $\mathrm{Ca}^{2+}$ signal was temporally distinct from the immediate $\mathrm{Ca}^{2+}$ signal induced on $\mathrm{LN}$-coated bead contact. The two $\mathrm{Ca}^{2+}$ signals were also functionally distinct with respect to their association with two independent growth cone behaviors, i.e., turning versus increased growth cone motility, both clearly separated in time.

In the standard assay the delayed, sustained $\mathrm{Ca}^{2+}$ signal and the period of increased rates of outgrowth depended on CaMkinase II activity. Very similarly, an influx of extracellular $\mathrm{Ca}^{2+}$ and CaM-kinase II activity were both essential for turning and navigation of growth cones toward a gradient of acetylcholine (Zheng et al., 1994). CaM-kinase II activity, downstream of a $\mathrm{Ca}^{2+}$ influx, was specifically required for neurite outgrowth promoted by L1, NCAM, and $N$-cadherin (Williams et al., 1995). Other investigations also link increased CaM-kinase II activity with the promotion of neurite elongation and growth cone motility (Goshima et al., 1993; Solem et al., 1995; Zou and Cline, 1996; Masse and Kelly, 1997). CaM-kinase II, often associated with actin filaments, can phosphorylate tubulin among various other substrates (Goldenring et al., 1983). Such a modification of tubulin could, in principle, alter microtubule assembly as well as growth cone motility. Many investigations have demonstrated 
that CaM-kinase II is critically involved in the conversion of single spike-like $\mathrm{Ca}^{2+}$ signals into sustained messages, because autophosphorylation of CaM-kinase II results in a $\mathrm{Ca}^{2+} / \mathrm{CaM}$ independent state of sustained kinase activity (Fong et al., 1989) (for review, see Hanson and Schulman, 1992). In this respect, it is an intriguing coincidence that sustained effects on growth cone motility apparently were associated with sustained CaM-kinase II activity.

In summary, it becomes increasingly evident that a complex network of signaling molecules is coordinated precisely in space, time, and activity when growth cones perform even the simplest pathfinding task: translating guidance information provided by a single molecule into navigational changes. Additional complexity could evolve from long-lasting activation of signaling molecules that, consequently, influence future navigational decisions of a single growth cone.

\section{REFERENCES}

Alexander KA, Cimler BM, Meier KE, Storm DT (1987) Regulation of calmodulin binding to P-57. J Biol Chem 262:6108-6113.

al-Mohanna FA, Cave J, Bolsover SR (1992) A narrow window of intracellular calcium concentration is optimal for neurite outgrowth in rat sensory neurons. Brain Res Dev Brain Res 70:287-290.

Alvarez J, Montero M, Garcia-Sandro J (1991) Cytochrome P-540 may link intracellular $\mathrm{Ca}^{2+}$ stores with plasma membrane $\mathrm{Ca}^{2+}$ influx. Biochem J 274:193-197.

Bedlack RS, Wei MD, Loew LM (1992) Localized membrane depolarizations and localized calcium influx during electric field-guided neurite growth. Neuron 9:393-403.

Bentley D, Guthrie PB, Kater SB (1991) Calcium ion distribution in nascent pioneer axons and coupled preaxogenesis neurons in situ. J Neurosci 11:1300-1308.

Bixby JL, Grunwald GB, Bookman RJ (1994) $\mathrm{Ca}^{2+}$ influx and neurite growth in response to purified $N$-cadherin and laminin. J Cell Biol 127:1461-1475.

Bolsover SR, Spector I (1986) Measurements of calcium transients in the soma, neurite, and growth cone of single cultured neurons. J Neurosci 6:1934-1940.

Brocke L, Srinivasan M, Schulman H (1995) Developmental and regional expression of multifunctional $\mathrm{Ca}^{2+} /$ calmodulin-dependent $\mathrm{ki}-$ nase isoforms in rat brain. J Neurosci 15:6797-6808.

Campenot RB, Draker DD (1989) Growth of sympathetic nerve fibers in culture does not require extracellular calcium. Neuron 3:733-743.

Chang HY, Takei K, Sydor AM, Born T, Rusnak F, Jay DG (1995) Asymmetric retraction of growth cone filopodia following focal inactivation of calcineurin. Nature 376:686-690.

Chien C, Rosenthal DE, Harris WA, Holt CE (1993) Navigational errors made by growth cones without filopodia in the embryonic Xenopus brain. Neuron 11:237-251.

Clapham DE (1995) Calcium signaling. Cell 80:259-268.

Davenport RW, Dou P, Rehder V, Kater SB (1993) A sensory role for neuronal growth cone filopodia. Nature 361:721-724.

Davenport RW, Dou P, Mills LR, Kater SB (1996) Distinct calcium signaling within neuronal growth cones and filopodia. J Neurobiol 31:1-15.

Doherty P, Walsh FS (1994) Signal transduction events underlying neurite outgrowth stimulated by cell adhesion molecules. Curr Opin Neurobiol 4:49-55.

Doherty P, Ashton SV, Moore SE, Walsh FS (1991) Morphoregulatory activities of NCAM and $N$-cadherin can be accounted for by G-proteindependent activation of $\mathrm{L}$ - and $\mathrm{N}$-type neuronal calcium channels. Cell 67:21-34

Fan J, Raper JA (1995) Localized collapsing cues can steer growth cones without introducing their full collapse. Neuron 14:263-274.

Fields RD, Guthrie PB, Russell JT, Kater SB, Malhorta BS, Nelson PG (1993) Accommodation of mouse DRG growth cones to electrically induced collapse: kinetic analysis of calcium transients and set-point theory. J Neurobiol 24:1080-1098.

Fong YL, Taylor WL, Jeans AR, Sonderling TR (1989) Studies of the regulatory mechanism of $\mathrm{Ca}^{2+} /$ calmodulin-dependent protein kinase II. Mutation of threonine 286 to alanine and aspartate. J Biol Chem 264:26759-26763.
Ghosh A, Greenberg ME (1995) Calcium signaling in neurons: molecular mechanisms and cellular consequences. Science 268:239-247.

Goldenring JR, Gonzales B, McGuire JS (1983) Purification and characterization of a calmodulin-dependent kinase from rat brain cytosol able to phosphorylate tubulin and microtubule-associated protein. J Biol Chem 258:12632-12640.

Gomez TM, Snow DM, Letourneau PC (1995) Characterization of spontaneous calcium transients in nerve growth cones and their effect on growth cone migration. Neuron 14:1233-1246.

Goodman CS, Shatz CJ (1993) Developmental mechanisms that generate precise patterns of neuronal connectivity. Cell 72/Neuron 10[Suppl]:77-98.

Goshima Y, Ohsako S, Yamauchi T (1993) Overexpression of $\mathrm{Ca}^{2+}$ / calmodulin-dependent protein kinase II in Neuro2A and NG108-15 neuroblastoma cell lines promotes neurite outgrowth and growth cone motility. J Neurosci 13:559-567.

Gottmann K, Lux HD (1995) Growth cone calcium ion channels: properties, clustering, and functional roles. Perspect Dev Neurobiol 2:371-377.

Grynkiewicz G, Poenie M, Tsien RY (1985) A new generation of $\mathrm{Ca}^{2+}$ indicators with greatly improved fluorescence properties. J Biol Chem 260:3440-3445.

Hait WN, Glazer L, Kaiser C, Cross J, Kennedy KA (1987) Pharmacological properties of fluphenazine-mustard, an irreversible calmodulin antagonist. Mol Pharmacol 32:404-409.

Hanson PI, Schulman H (1992) Neuronal $\mathrm{Ca}^{2+} /$ calmodulin-dependent protein kinases. Annu Rev Biochem 61:559-601.

Harper SJ, Bolsover SR, Walsh FS, Doherty P (1994) Neurite outgrowth stimulated by L1 requires calcium influx into neurons but is not associated with changes in steady state levels of calcium in growth cones. Cell Adhes Commun 2:441-453.

Haydon PG, McCobb DP, Kater SB (1984) Serotonin selectively inhibits growth cone motility and the connectivity of identified neurons of Helisoma. J Neurosci Res 13:135-147.

Holliday J, Spitzer NC (1990) Spontaneous calcium influx and its roles in differentiation of spinal neurons in culture. Dev Biol 141:13-23.

Hynes RO, Lander AD (1992) Contact and adhesive specificities in the association, migration, and targeting of cells and axons. Cell 86:303-322.

James P, Vorherr T, Carafoli E (1995) Calmodulin-binding domains: just two-faced or multi-faceted? Trends Biochem Sci 20:38-42.

Kater SB, Mills LR (1991) Regulation of growth cone behavior by calcium. J Neurosci 11:891-899.

Kater SB, Rehder V (1995) The sensory-motor role of growth cone filopodia. Curr Opin Neurobiol 5:68-74.

Kuhn TB, Schmidt MF, Kater SB (1995) Laminin and fibronectin guideposts signal sustained by opposite effects to passing growth cones. Neuron 14:275-285.

Letourneau PC, Snow DM, Gomez TM (1994) Growth cone motility: substratum-bound molecules, cytoplasmic $\left[\mathrm{Ca}^{2+}\right]$, and $\mathrm{Ca}^{2+}$-regulated proteins. Prog Brain Res 102:35-48.

Li M, Shibata A, Li C, Braun RE, McKerracher L, Roder J, Kater SB, David S (1996) Myelin-associated glycoprotein inhibits neurite/axon growth and causes growth cone collapse. J Neurosci Res 46:404-414.

Masse T, Kelly PT (1997) Overexpression of $\mathrm{Ca}^{2+} /$ calmodulindependent protein kinase II in PC12 cells alters cell growth, morphology, and nerve growth factor-induced differentiation. J Neurosci 17:924-931.

Mattson MP, Kater SB (1987) Calcium regulation of neurite outgrowth and growth cone motility. J Neurosci 7:4034-4043.

O’Connor TP, Duerr JS, Bentley D (1990) Pioneer growth cone steering decisions mediated by single filopodial contact in situ. J Neurosci 10:3935-3946.

Rivas RJ, Burmeister DW, Goldberg DJ (1992) Rapid effects of laminin on the growth cone. Neuron 8:107-115.

Robson SJ, Burgoyne RD (1989) L-type calcium channels in the regulation of neurite outgrowth from rat dorsal root ganglion neurons in culture. Neurosci Lett 104:110-114.

Schuch U, Lohse MJ, Schachner M (1989) Neural cell adhesion molecules influence second messenger systems. Neuron 3:13-20.

Schulman $\mathrm{H}$ (1988) The multifunctional $\mathrm{Ca}^{2+} / \mathrm{CaM}$-dependent protein kinase. Adv Second Messenger Phosphoprotein Res 22:39-111.

Silver RA, Lamb AG, Bolsover SR (1990) Calcium hotspots caused by L-channel clustering promote morphological changes in neuronal growth cones. Nature 343:751-754. 
Sjaastad MD, Nelson WJ (1997) Integrin-mediated calcium signaling and regulation of cell adhesion by intracellular calcium. BioEssays 19:47-55.

Solem M, McMahon T, Messing RO (1995) Depolarization-induced neurite outgrowth in PC-12 cells requires permissive, low-level NGF receptor stimulation and activation of calcium/calmodulin-dependent protein kinase. J Neurosci 15:5966-5975.

Tanaka E, Sabry J (1995) Making the connection, cytoskeletal rearrangements during growth cone guidance. Cell 83:171-176.

Tokumitsu H, Chijiwa T, Hagiwara M, Mizutani A, Terasawa M, Hidaka H (1990) KN-62, I-[N,O-bis(5-isoquinolinesulfonyl)- $N$-methyl-L-tyrosyl]-4phenylpiperazine, a specific inhibitor of $\mathrm{Ca}^{2+} /$ calmodulin-dependent protein kinase II. J Biol Chem 265:4315-4320.

Toullec D, Pianetti P, Coste H, Bellevergue P, Grans-Perret T, Ajakane M, Baudet V, Biossin P, Boursier E, Loriolle F (1991) The bisindolylmaleimide gf $109203 \mathrm{X}$ is a potent and selective inhibitor of protein kinase C. J Biol Chem 266:15771-15781.

Tymianski M, Charlton MP, Carlen PL, Tator CH (1994) Properties of neuroprotective cell-permeant $\mathrm{Ca}^{2+}$ chelator: effects on $\left[\mathrm{Ca}^{2+}\right]_{\mathrm{i}}$ and glutamate neurotoxicity in vivo. J Neurophysiol 72:1973-1992.

VanBerkum MFA, Goodman CS (1995) Targeted disruption of $\mathrm{Ca}^{2+}$ calmodulin signaling in Drosophila growth cones leads to stalls in axon extension and errors in axon guidance. Neuron 14:43-56.
Von Bohlen und Halbach F, Taylor J, Schachner M (1992) Cell typespecific effects of the neural adhesion molecules L1 and NCAM on diverse second messenger systems. Eur J Neurosci 4:896-909.

Werth JL, Usachev YM, Thayer SA (1996) Modulation of calcium efflux from cultured rat dorsal root ganglion neurons. J Neurosci 16:1008-1015.

Williams EJ, Doherty P, Turner G, Reid AD, Hemperley JJ, Walsh FS (1992) Calcium influx into neurons can solely account for cell contactdependent neurite outgrowth stimulated by transfected L1. J Cell Biol 119:883-892.

Williams EJ, Mittal B, Walsh FS, Doherty P (1995) $\mathrm{A} \mathrm{Ca}^{2+} /$ calmodulin kinase inhibitor, KN-62, inhibits neurite outgrowth stimulated by CAMs and FGF. Mol Cell Neurosci 6:69-79.

Zheng J, Felder M, Connor JA, Poo M (1994) Turning of nerve growth cones induced by neurotransmitters. Science 368:140-144.

Zheng J, Wan J, Poo MM (1996) Essential role of filopodia in chemotropic turning of nerve growth cone induced by a glutamate gradient. J Neurosci 16:1140-1149.

Zou DJ, Cline HT (1996) Expression of constitutively active CaMKII in target tissue modifies presynaptic axon arbor growth. Neuron 16: $529-539$. 